\title{
KRYTYKOWANO I RADZONO WYRAŻANO SPRZECIW WOBEC DOTYCHCZASOWYCH NIEDOBRYCH PRAKTYK - BUDOWA „KRAJOWEGO” WIZERUNKU I SEKRETARZA KC PZPR EDWARDA GIERKA W POLSKIEJ KRONICE FILMOWEJ
}

Streszczenie. Kreacja wizerunku politycznego jest jednym z podstawowych elementów kampanii wyborczej w krajach demokratycznych, a w autorytaryzmach - propagandy. Dla sprawnego polityka może się to okazać cennym narzędziem, które w sposób niezwykle skuteczny pomoże w budowaniu jego pozycji w kraju, bądź na świecie.

Postać Edwarda Gierka, po przejęciu przez niego funkcji I sekretarza Komitetu Centralnego Polskiej Zjednoczonej Partii Robotniczej, nad wyraz często przedstawiano w różnych mediach. Nie mogło go także zabraknąć w Polskiej Kronice Filmowej. Nowy „pierwszy” zdecydowanie bardziej doceniał wagę korzystnego przedstawienia swojej osoby w środkach masowego przekazu, co widoczne było w ilości oraz specyfice materiałów z nim związanych. Niniejsza praca zajmuje się analizą sposobu ukazywania I sekretarza KC PZPR w tym medium, przedstawia pewne schematy kreacji jego wizerunku, a także zarysowuje zachodzące w nim na przestrzeni lat zmiany. W pracy następuje wyszczególnienie kilku płaszczyzn oraz charakterystycznych elementów budowy wizerunku Edwarda Gierka w kontekście krajowym. Poniższy/powyższy artykuł stara się także uchwycić cele tej kreacji. Autor korzystał z dostępnej literatury przedmiotu, zajmującej się Polską Kroniką Filmową, a także wizerunkiem politycznym. Dokonał ponadto analizy udostępnionych materiałów filmowych, a przede wszystkim list montażowych, które były szczegółowym opisem montażu kroniki, zawierającym spis ujęć wraz z opisem, a także komentarzem lektora.

Słowa kluczowe: Polska Kronika Filmowa, propaganda sukcesu, Edward Gierek, kreacja wizerunku, polityka, PRL, I sekretarz KC PZPR. 


\section{Wstęp}

E dward Gierek jako I sekretarz KC PZPR był w latach 1970-1980 najważniejszą osobą w państwie. W związku z systemem panującym w PRL-u, dalekim od demokracji, jego wizerunek próbowano kreować na różne sposoby. W swojej pracy starałem się uchwycić jak przedstawiano I sekretarza KC PZPR w Polskiej Kronice Filmowej, oraz czy można mówić o próbie budowy spójnej narracji. Temat ten wydaje się tym bardziej ciekawy, ponieważ widać znaczące różnice w przedstawianiu na ekranie jego poprzednika, Władysława Gomułki. Ramy czasowe z oczywistych względów zamykają się między grudniem 1970 r. a sierpniem 1980 r., ponieważ właśnie w tym czasie E. Gierek piastował funkcję I sekretarza KC, a co za tym idzie można było myśleć o budowaniu spójnego wizerunku przedstawiającego go jako męża stanu. Zarówno przed, jak i po dekadzie lat siedemdziesiątych nie było możliwości tak skutecznej kreacji w ogólnopolskim medium.

W niniejszym artykule pozwoliłem zawęzić zakres tematyczny do wątków „krajowych”, ponieważ dostrzegam w nich spójną konstrukcję, która pozwalała przedstawiać E. Gierka w pozytywnym, paternalistycznym świetle. Mam także wrażenie, że była budowana w inny sposób niż materiały ukazujące go na arenie międzynarodowej (co przypadku „otwarcia na zachód” było niezwykle istotne). W tekście pojawia się jednak Leonid Breżniew, głowa państwa. Pozwoliłem zawrzeć kilka materiałów z jego osobą, ponieważ ich znaczenie w kontekście „krajowym” było niezwykle istotne, a wątki rocznicowe oraz partyjne w bloku wschodnim charakteryzowały się własną specyfiką.

W swojej pracy korzystałem z różnych materiałów źródłowych związanych z PKF. Były to przede wszystkim listy montażowe $\mathrm{z}$ wspomnianego wcześniej okresu, a które powstawały podczas realizacji każdej kroniki. Znajdują się one w Filmotece Narodowej Instytucie Audiowizualnym. Opierałem się na materiałach filmowych zamieszczonych na stronie internetowej tej instytucji oraz oryginalnych taśmach. Oglądałem także nagrania udostępnione na portalu Kronika $\mathrm{RP}^{1}$ oraz YouTube i je także uwzględniłem w artykule. Podczas pisania pracy korzystałem także z pamiętników i wspomnień dygnitarzy partyjnych, redaktorów, niektórych osób związanych z PKF oraz materiałów rocznicowych.

W przypadku kroniki warto podkreślić fakt, że sceny niekorzystne często nie były umieszczane w jej finalnej wersji (umieszczono je w tzw. odrzutach). Nie wynikało to z celowego kreowania wizerunku, lecz z chęci przedstawienia konkretnej osoby w dobrym świetle (dotyczyło to zwłaszcza rządzących).

\footnotetext{
${ }^{1}$ http://www.kronikarp.pl, dostęp: 23.04.2017.
} 


\section{Propaganda w latach siedemdziesiątych i kreacja wizerunku}

Na samym początku należy zadać sobie pytanie, czym jest propaganda? W książce z epoki można znaleźć informację, że w jej skład wchodził m.in. wpływ na postawy, myślenie i działanie odbiorców ${ }^{2}$. Termin ten łączy się często ze słowem manipulacja, które wspólnie dają wrażenie zdecydowanie negatywne. Próby stworzenia definicji tegoż zagadnienia podjął się w książce Propaganda a polityka Rudolf Borecki. Manipulacja propagandowa to dla niego

ukierunkowane przekształcenie świadomości społecznej, polegające na zamierzonym odchyleniu od odzwierciedlanego przez nią bytu społecznego w procesie pośredniego poznania rzeczywistości przez środki masowego przekazu33.

Z racji istnienia w PRL-u Głównego Urzędu Kontroli Prasy, Publikacji i Widowisk wydaje się oczywiste, że informacje przekazywane przez media, w tym PKF nie mogły być w pełni obiektywne, a zatem stanowiły fragment manipulacji propagandowej".

Wraz ze zmianą władzy w końcu 1970 r. musiała nastąpić pewna zmiana retoryki partyjnej, a co za tym idzie stylu propagandy stosowanego dotychczas przez ludzi związanych z W. Gomułką. W przypadku jego następcy - E. Gierka, osoby spoza kręgu warszawskiego partii i popularnego przede wszystkim na Śląsku, ważnym elementem musiała być kreacja wizerunku, w której mógł pomóc wygląd I sekretarza KC. Prezentował się bowiem dużo korzystniej od swojego poprzednika, miał dużo przyjemniejszy styl wymowy, a także sprawiał wrażenie młodszego niż był w rzeczywistości. Gdy dany przywódca prezentuje się dobrze, ludzie są bardziej przekonani do tez przez niego głoszonych.

Zabiegi te wpisują się w zjawisko marketingu politycznego, którego celem jest wpływ na społeczeństwo, by wybrało ono danego kandydata, grupę, czy też projekt polityczny 5 . W przypadku PRL-u, gdzie zapewniona była kierownicza rola PZPR, zadania musiały być nieco odmienne. Nie trzeba było wybierać między konkurentami, a jedynie poprzeć władze i ich działania podejmowane na scenie politycznej, czy też społecznej. Brakowało również elementu charakterystycznego dla wyborów w czasach kapitalizmu - oficjalnej walki z konkurentami. Wydaje mi się, że jej elementów można doszukiwać się jedynie w krytyce poprzedniego kierownictwa, które miało

\footnotetext{
2 J. Mazurek, Z teorii propagandy socjalistycznej, Warszawa 1974, s. 138-139.

${ }^{3}$ R. Borecki, Propaganda a polityka, Warszawa 1987, s. 122.

${ }^{4}$ http://www.kronikarzprl.com.pl/spis-tre\%C5\%9Bci/9-cenzura/, dostęp: 9.07.2017.

5 P. Kotler, Marketing. Analiza, planowanie, wdrażanie i kontrola, Warszawa 1994, s. 6.
} 
doprowadzić do zapaści gospodarczej, a w konsekwencji napięć społecznych, a także w czasie kampanii mającej wzmocnić poparcie dla I sekretarza po czerwcu $1976 \mathrm{r}$.

W systemach komunistycznych wizerunek polityczny był niezwykle istotny ze względu na rolę jaką pełnił partyjny przywódca. Definicja wskazuje, że tworzy go zespół cech posiadanych przez polityka (oczywiście zdaniem odbiorców). W jego skład wchodzą różne komponenty. Najważniejszymi z nich na gruncie polskim są:

- zakorzenienie geograficzne;

- wartości związane z grupą społeczną;

- wykształcenie i zawód;

- wyznanie ${ }^{6}$.

W przypadku E. Gierka każdy z tych elementów był przynajmniej pośrednio akcentowany w materiałach PKF. Szczególnie ważny i najbardziej dostrzegalny wydawał się być akcent (kontekst) geograficzny, wiążący E. Gierka ze Śląskiem. Kolejne dwa aspekty w przypadku I sekretarza łączą się ze sobą. Często w kronikach podkreślano jego górnicze pochodzenie, zarówno w materiałach zza granicy, jak i kraju. Wykształcenie mogła zastępować znajomość języków obcych. Wątek religijny podkreślony był szczególnie przez relacje z papieżem Pawłem VI i Janem Pawłem II. Sprawiało to wrażenie, że mimo iż przywódca PZPR był ateistą, potrafił otworzyć się na dialog z kościołem, w przeciwieństwie do swojego poprzednika.

Ważnym elementem są też cechy składowe wizerunku politycznego, z których najistotniejszymi były:

- zdolności przywódcze (np. umiejętność sprawowania przywództwa, liberalizm, roztropność)

- cechy jako lidera (np. poważanie, uczciwość, lojalność)

- zdolności komunikacyjne (np. szczerość, wprawa, błyskotliwość, energia)

- cechy osobiste (np. niekonfliktowość, zdolność budzenia sympatii) ${ }^{7}$.

Wizerunek polityka należy odpowiednio wypracować. Proces jego tworzenia możemy podzielić na trzy aspekty. Pierwszym z nich jest próba wzmocnienia już posiadanego, drugim przedstawienie jego przeciwieństwa, trzecim zaś kreacja od zera (gdy nie jest on znany szczerszemu gronu

\footnotetext{
${ }^{6}$ Ibidem, s. 63.

7 Z.J. Pietraś, Decydowanie polityczne, Warszawa 1998, s. 230-235.
} 
odbiorców $)^{8}$. W przypadku E. Gierka każdy z wątków pojawiała się w pewnym okresie. $\mathrm{Z}$ jednej strony był już obecny w polityce i utożsamiany jako „dobry gospodarz” na Śląsku9. Z drugiej zaś radykalnie skrytykował wystąpienia studentów w $1968 \mathrm{r}^{10}$. Wreszcie nie był on tak powszechnie znany w całym kraju, przez co mógł być narażony na liczne perturbacje wewnątrz partii, z racji słabej pozycji i niskiego kredytu zaufania (w przeciwieństwie do Gomułki w 1956 r.) ${ }^{11}$.

\section{Uroczystości państwowe}

Uroczystości państwowe to niezbędny element legitymizacji władzy, podczas której (przynajmniej teoretycznie) może się ona spotkać z obywatelem. W czasach komunistycznych w Polsce zmieniła się liczba świąt państwowych, które uroczyście obchodzono. Spośród nowo ustanowionych najważniejszymi, a także istotnymi dla potrzeb niniejszego artykułu były:

- Narodowe Święto Odrodzenia Polski obchodzone od 1945 r. ${ }^{12}$ w dniu 22 lipca na cześć ogłoszenia Manifestu PKWN;

- 1 maja, oficjalnie ustanowione od 1950 r. ${ }^{13}$, zwane także Świętem Pracy;

- 9 maja- Narodowe Święto Zwycięstwa i Wolności ustanowione w 1945 r. $^{14}$;

- Dzień Wojska Polskiego, obchodzony od $1950 \mathrm{r}^{15} \mathrm{w}$ rocznicę bitwy pod Lenino tj. 12 października.

Równie ważną uroczystością były dożynki, które przyjęły charakter ogólnopolski, pod nazwą „Dożynek centralnych”. W PRL-u miały niezwykle rozbudowany charakter, co mogło być podkreśleniem roli wsi w ówczesnej rzeczywistości, jako podstawowego elementu składowego państwa. Co istotne dla tekstu, I Sekretarz KC PZPR był obecny na niektórych lokalnych uroczystościach dożynkowych, z których nagrania wykorzystywano w PKF.

Kolejnymi istotnymi wydarzeniami, w których brał udział I Sekretarz były obchody rocznicowe. Zdecydowanie najważniejszym z nich było XXX-lecie PRL-u, wiążące się z serią ogólnopolskich i lokalnych uroczystości

\footnotetext{
8 Ibidem, s. 70-71.

9 J. Eisler, Siedmiu wspaniałych. Poczet pierwszych sekretarzy KC PZPR, Warszawa 2014, s. 271.

10 Ibidem, s. 273.

11 Ibidem, s. 277.

12 Dz.U. z 1945 r. Nr 32, poz. 194.

13 Dz.U. z 1950 r. Nr 19, poz. 157.

14 Dz.U. z 1945 r. Nr 21, poz. 116.

15 Dz.U. z 1950 r. Nr 45, poz. 411.
} 
przedstawianych później w PKF. Musiało ono mieć podniosłe znaczenie, ponieważ podczas obchodów pojawił się Sekretarz Generalny Komunistycznej Partii Związku Radzieckiego L. Breżniew.

Co interesujące E. Gierek sporadycznie brał udział w uroczystościach związanych z wojskiem. Być może było to spowodowane małym zainteresowaniem kwestiami militarnymi, dzięki czemu gen. W. Jaruzelski wyrobił sobie w armii silną pozycję ${ }^{16}$, wzrastającą wraz z kolejnymi latami władzy Gierka ${ }^{17}$.

Idąc zgodnie z kalendarzem uroczystości państwowych, na początku zajmę się pochodami pierwszomajowymi. Niewątpliwie w PRL-u 1 maja był jednym z najważniejszych świąt, które miało pokazać łączność ludu pracującego miast i wsi pod egidą władz. Miały miejsce rokrocznie i były silnie wpisane w nurt uroczystości państwowych, a I sekretarz KC PZPR był na nich zawsze obecny. Szczególnie widoczne w materiałach PKF związanych z pochodami pierwszomajowymi było nastawienie na pokazywanie uczestników parad i pochodów - w końcu było to ich święto. Na ekranach można było zobaczyć także inne atrakcje odbywające się już po głównych obchodach.

W związku z powtarzalnością uroczystości możemy powiedzieć o pewnym schemacie każdorocznej relacji w PKF. Postać E. Gierka nie była jej najważniejszym elementem, jednak stanowiła coś na wzór punktu centralnego, wokół którego skupiały się obchody. Na I sekretarza co jakiś czas padało zbliżenie kamery, najczęściej podczas pozdrawiania tłumu, czy otrzymywania kwiatów od dzieci i osób dorosłych. Równie często odrzucał je uczestnikom pochodu. W trakcie uroczystości zdarzała się nawet wymiana upominków. Pomimo tego ważniejszym wydaje się pokazanie znanych i powszechnie lubianych postaci. Byli nimi aktorzy, sportowcy czy pisarze uczestniczący w pochodzie, którzy pozdrawiali dygnitarzy partyjnych i rządowych. Ludzi znanych wymieniał lektor podczas zbliżenia na ich twarze. Być może miało to za zadanie pokazać poparcie autorytetów dla ówczesnej ekipy, co mogło wpłynąć przekonująco na widzów. Szczególnie na początku lat siedemdziesiątych można było $\mathrm{w}$ ten sposób próbować legitymizować nową władzę, a także ukazać ją w przyjaznym świetle. Stanowiło to także kontrast wobec wcześniejszych rządów, skompromitowanych rozprawą z inteligencją w $1968 \mathrm{r}$.

Także migawki na maszerujący tłum - przedstawicieli zakładów pracy, weteranów, a także dzieci miały pokazać siłę i jedność skupioną wokół I sekretarza KC PZPR. Istotnym jest, że podczas tych uroczystości silnie akcentowany był udział najmłodszych, w tym ich kontakt z E. Gierkiem np. poprzez trzymanie na ręku czy wręczanie kwiatów. Działania te mogły

\footnotetext{
16 L. Kowalski, Generał ze skaza, Poznań 2012, s. 398-399, 460-461.

17 Ibidem, s. 489-490.
} 
potęgować jego obraz jako kogoś w rodzaju „ojca narodu”18. Niemniej jednak sylwetka I sekretarza nie pojawiała się zbyt długo na ekranie, dzięki czemu podczas relacji można było zobaczyć większą liczbę maszerujących, co zapewne miało wpłynąć na uatrakcyjnienie materiału oraz wskazać na szerokie poparcie.

Spośród ogółu materiałów filmowych dotyczących pochodów pierwszomajowych w PKF pojawiły się dwa odstępstwa od reguły. Przejawiały się w tym, że tuż po zajęciu miejsca na trybunie honorowej przedstawiono transmisję przemówienia E. Gierka. Miało to miejsce w kronice z 1974 i 1978 r. W pierwszej z nich było przytoczone w całości, natomiast w następnej tylko opatrzone komentarzem lektora.

W materiałach PKF zmianom ulegał przede wszystkim wstęp filmowy przed samym pochodem. W relacji z 1 maja 1971 r. znaczną część stanowiły same przygotowania do obchodów i rozmowa z ludźmi na temat prognozy pogody: jaka będzie pogoda na 1-go maja, jak się ubrać na pochód ${ }^{19}$, które stanowiły początek materiału ${ }^{20}$. Podkreślenie tych ujęć mogło wskazywać na próbę zmniejszenia dystansu między organizatorami, czyli PZPR a uczestnikami. Dopiero po nich lektor wspominał, że w tym roku przedstawiciele władzy zanim zasiądą na trybunie honorowej sami przejdą w pierwszym szeregu pochodu. Miało to pokazać zmianę jaka nastąpiła po przejęciu władzy przez E. Gierka i większym otwarciu na społeczeństwo. Wskazywało także, iż władze partyjne stanowiły awangardę PZPR i prowadziły naród ku lepszej przyszłości. Co godne zaznaczenia, także w kolejnych latach fakt wspólnego pochodu był mocno podkreślany ${ }^{21}$. Z tej nowej, „świeckiej tradycji" wyłamały się jedynie marsze z 1973, 1977 i 1980 r. W PKF w 1973 r. po wstępie ukazującym wybrane miasta Polski i zakłady przemysłowe, pojawiła się postać E. Gierka od razu na trybunie ${ }^{22}$, zaś w materiale z 1977 r. trybunę honorową z I sekretarzem ukazano po zapowiedzi ${ }^{23}$. Początek kroniki z 1975 r. przedstawiał natomiast wręczanie odznaczeń przez towarzysza sekretarza weteranom i przodownikom pracy ${ }^{24}$, co być może miało związek ze zbliżającą się trzydziestą rocznicą zakończenia II wojny światowej.

18 M. Rakowski, Dzienniki polityczne 1976-1978, Warszawa 2002, s. 30, 40, 283; idem, Dzienniki polityczne 1979-1981, Warszawa 2004, s. 167.

19 Lista montażowa PKF 18A/71, https://www.youtube.com/watch?v=2X4stbnNWDA\&t=68s, dostęp: 22.05.2017.

20 Ibidem.

21 To już tradycyjny symbol wspólnego marszu mówi lektor w kronice o 1 maja 1975 r., lista montażowa PKF 18B/75.

22 Lista montażowa PKF 18A/73.

23 Lista montażowa PKF 18A/77.

24 Lista montażowa PKF 18B/75. 
Pozostałe materiały z tzw. „dekady Gierka” nie posiadały wstępu i od razu pojawiała się relacja z uroczystości. Pochód z 1979 r. wzbogacono o przedstawienie przygotowań do przemarszu, a także o częste najazdy kamery na zgromadzone dzieci. Interesujące są natomiast materiały znajdujące się w odrzutach. W pierwszym E. Gierek przedstawiony był w trakcie pochodu z włożoną do kieszeni ręką - być może ujęcie zostało usunięte ze względu na nie wyjściowy charakter. Pominięto także kadry, w których dziecko wręczyło mu kwiaty, a w zamian otrzymało cukierek, co mogło nasuwać skojarzenie z popularnym powiedzeniem chcesz cukierka idź do Gierka ${ }^{25}$ i wpłynęłoby negatywnie na jego wizerunek. Najbardziej odmiennym w stosunku do reszty materiałów był pochód z $1980 \mathrm{r}$. Na samym początku relacji pojawił się przemarsz młodzieży, a następnie ludzi pracy. Górnicy i hutnicy zostali przyjęci przez E. Gierka na trybunie honorowej. Poinformowali dygnitarzy partyjnych o wynikach swej trudnej i odpowiedzialnej pracy ${ }^{26}$. Umieszczenie takiego fragmentu w relacji z pochodu mogło być ukłonem w stronę grup społecznych bliskich I sekretarzowi, a także mogło wskazywać na rozwój produkcji mimo różnorakich przeciwności. Nieodległy kryzys z 1979 r. może potwierdzać tę tezę. Niewykluczone, że liczył również na oparcie w najbardziej oddanych mu grupach zawodowych.

Następną ważną uroczystością było obchodzone 22 lipca Narodowe Święto Odrodzenia Polski, które stanowiło jeden z mitów założycielskich PRL-u. Jednak w PKF obecne były jedynie relacje z dwóch lat, w których pojawiła się postać E. Gierka, a wiążących się z tym wydarzeniem.

W związku z XXX-leciem Polski Ludowej w PKF ukazały się dwa zbliżone do siebie materiały o sygnaturach 30A/74 i 33AB/74 (czyli wyświetlanym dwukrotnie), co świadczy, że relacja z tych uroczystości pojawiała się w kinach trzykrotnie. Druga z kronik była obszerna - trwała około 19 minut i stanowiła rozbudowaną wersję swojej poprzedniczki. Składała się z dwóch części. W pierwszej przedstawiono sukcesy ekipy gierkowskiej odniesione na kanwie rozbudowy kraju, ze szczególnym podkreśleniem prac ukończonych przed planowanym terminem, następnie zaś pojawiły się główne uroczystości i związana z tym wizyta L. Breżniewa w Polsce.

Początek materiału stanowiła relacja z uroczystości odbywających się w kolebce ludowej państwowości $i^{27}$ Chełmie Lubelskim. E. Gierka przedstawiono podczas przybycia na wiec wraz z dygnitarzami partyjnymi wśród

${ }^{25}$ http://www.gazetakrakowska.pl/artykul/732281,chcesz-cukierka-idz-do-gierka,id,t. html, dostęp: 14.05.2017.

${ }^{26}$ Lista montażowa PKF 18B/80.

${ }^{27}$ Lista montażowa PKF 33AB/74. 
tłumu zgromadzonych. Próbą ocieplenia wizerunku I sekretarza mogło być ujęcie, w którym wręczał różę napotkanej kobiecie. Następnie lektor informował o odznaczeniu województwa lubelskiego Orderem Budowniczych Polski Ludowej, a Chełma Krzyżem Wielkim Orderu Odrodzenia Polski ${ }^{28}$. W ten sposób uhonorowano tereny, na których powstawało nowe państwo polskie. Następnie pojawił się na otwarciu trasy W-Z, którą wedle informacji lektora wybudowano w rekordowym tempie. Dostał wówczas kwiatek od chłopca, co zapewne miało wzbudzić sympatię wśród widzów. W dalszej kolejności przedstawiono relację $\mathrm{z}$ odbudowy Zamku Królewskiego, który również został ukończony w zawrotnym czasie. Zabrakło wówczas E. Gierka, obecnego jednak w następnych ujęciach podczas otwarcia trasy łazienkowskiej. Podkreślenie rekordowych sukcesów wpisywało się zarówno w obchody XXX-lecia, jak i kreowany wizerunek I sekretarza. Szybki rozwój kraju miał bowiem nastąpić dzięki E. Gierkowi, ponieważ wezwał on do budowania II Polski ${ }^{29}$. Podobny przekaz miały spotkania w kopalniach (gdzie pojawił się w stroju roboczym, co podkreślało znajomość pracy pod ziemią) oraz wizyty w Głogowie i Porcie Północnym. Za każdym razem swobodnie rozmawiał z robotnikami i inżynierami, co wskazywało na zainteresowanie tematem, a także przystępność wobec obywateli. Materiały przeplatała wizyta na Powązkach, podczas której składał wieńce na grobach Marcelego Nowotki, Bolesława Bieruta i Aleksandra Zawadzkiego. Jest to interesujące odwołanie do „starych” komunistów, silnie związanych z ZSRR. Być może celem tej relacji było podkreślenie rodowodu komunizmu w Polsce, co stanowiłoby ukłon I sekretarza w stronę ZSRR. Gierek pojawił się także na forum Polonii, co mogło być zaznaczeniem otwartości państwa polskiego, a także gestem w stronę środowiska emigrantów.

Druga część materiału przedstawiała główne uroczystości, które poprzedzone były relacją z przybycia L. Breżniewa. Po wyjściu z samolotu wylewnie witał się z E. Gierkiem, co mogło świadczyć o wyrazach uznania skierowanych wobec polskiego przywódcy. Następnie przywitał się z dygnitarzami partyjnymi. Lektor podkreślił, że udział sekretarza generalnego KPZR był dowodem serdecznej współpracy między państwami. Kolejny fragment stanowiło przejście przed kompanią honorową ${ }^{30}$.

Ważniejsza jest jednak następna część materiału. Właśnie wtedy gość ze wschodu przejeżdżał otwartym samochodem wraz z E. Gierkiem wśród tłumów zgromadzonych na ulicach Warszawy.

\footnotetext{
${ }^{28}$ Ibidem.

${ }^{29}$ M. Rakowski, Dzienniki polityczne 1972-1975, Warszawa 2002, s. 205.

${ }^{30}$ Lista montażowa PKF 33AB/74.
} 
Obecni na trasie przejazdu entuzjastycznie witali sekretarza generalnego, wielu warszawiaków trzymało w rękach jego portrety ${ }^{31}$. Przywódcy byli zatrzymywani przez zespół Mazowsze, a także wręczających kwiaty. Szczególnie podkreślono tutaj małą dziewczynkę, którą L. Breżniew zabrał na ręce i przytulił. Wydaje się, że był to ukłon w stronę sekretarza generalnego, który miał zagrać na jego uczuciach i wzmocnić pozycję I sekretarza. Interesujący jest natomiast fakt usunięcia w tym materiale ujęć innej, młodej dziewczyny, które były zawarte w kronice 30A/74. Wspomniana dziewczyna wiązała na szyi sekretarza generalnego chustkę, co miało wywołać komentarze widzów domagające się uduszenia L. Breżniewa ${ }^{32}$. Ten fragment kroniki zakończyło złożenie wieńców przy Grobie Nieznanego Żołnierza i cmentarzu żołnierzy radzieckich.

Kolejną część stanowiła relacja z odwiedzin Śląska. Sekretarzowi generalnemu wręczono legitymację i tytuł honorowego członka załogi budującej hutę Katowice, po czym w swojskiej atmosferze rozmawiał z robotnikami ${ }^{33}$. Przywódcę radzieckiego przedstawiono w górniczym mundurze galowym, po czym wśród tłumów (znów schemat podobny do tego z Warszawy) przyjechał na wiec w Katowicach. Wręczono mu honorowy tytuł obywatela województwa katowickiego i łańcuch z herbami miast śląskich, za co sekretarz generalny serdecznie podziękował ${ }^{34}$. Cały czas towarzyszył mu E. Gierek.

Punktem kulminacyjnym wręczania godności stało się odznaczenie L. Breżniewa Krzyżem Wielkim Orderu Virtuti Militari, co dla wielu było oznaką podporządkowania wobec ZSRR. Działanie takie wraz z poprzednimi godnościami miało na celu wzbudzić zaufanie i zadowolenie sekretarza generalnego, co w pełni się udało ${ }^{35}$. I sekretarz otrzymał zaś od gościa ze wschodu okolicznościowy puchar. Zaznaczono także uroczyste ślubowanie młodzieży, w obecności obu przywódców.

Całość relacji zamknęła defilada. E. Gierek i L. Breżniew stali na trybunie honorowej w czasie gdy prezentowało się wojsko. Przemarsz nie był tak efektowny jak z okazji Tysiąclecia Państwa Polskiego. Przywódcy zostali ukazani w czasie pozdrowień żołnierzy. Pochód zamknęło przejście młodzieży, co wpisywało się w propagandę przedstawiającą I sekretarza jako orędownika ludzi młodych. Wydaje się, że ta kronika zawierała naj-

${ }^{31}$ Sam Edward Gierek odwrócił się od tradycji rozwieszania portretów I sekretarzy.

32 M. Cieśliński, Piękniej niż w życiu. Polska Kronika Filmowa 1944-1994, Warszawa 2006, s. 126.

33 Lista montażowa PKF 33AB/74.

${ }^{34}$ Ibidem.

${ }^{35}$ E. Gierek wspomina, że L. Breżniew stawał się coraz bardziej zachłanny na zaszczyty, co wykorzystał w czasie tych uroczystości. J. Rolicki, Edward Gierek. Przerwana dekada, Warszawa 1990, s. 94. 
ważniejsze elementy kampanii propagandowej E. Gierka w pierwszej połowie lat siedemdziesiątych.

Kolejnymi uroczystościami jakie na stałe zagościły w PKF były dożynki. W każdym kolejnym roku pojawiały się relacje ze „święta wsi”. Wraz z upływem lat widać stopniową zmianę punktu ciężkości tego wydarzenia. E. Gierka w mniejszym stopniu przedstawiano w trakcie uroczystości, nacisk zaś kładziono na rolników i program artystyczny.

W pierwszym materiale z 1971 r. polski przywódca na samym początku dekorował odznaczeniami mieszkańców wsi. W kolejnych ujęciach był przedstawiony podczas otrzymania chleba od starostów, z którym obchodził się z należytym szacunkiem - ucałował go i ostrożnie odłożył na honorowe miejsce. Przytoczono przemowę I sekretarza, w której dziękował za dar ludności wiejskiej. Następnie pocałował w rękę starościnę dożynek i pogratulował młodej parze z zespołu „Śląsk”, co mogło wskazywać na znaczenie wartości rodzinnych. W późniejszych kadrach przedstawiony był za stołem, skąd obserwował dalszy przebieg uroczystości. W czasie relacji z programu artystycznego pojawiały się zbliżenia na klaszczącego Gierka ${ }^{36}$.

W kolejnych latach uroczystości przebiegały bardzo podobnie. W $1972 \mathrm{r}$. na samym początku materiału przedstawione były dzieci - przyszłość narodu, które witały przybywającego I sekretarza ${ }^{37}$. Kolejne części nie odbiegały w sposób znaczny od kroniki z $1971 \mathrm{r}$.

W 1973 r.w PKF pojawiły się dwie relacje związane z dożynkami. W pierwszej przedstawiono zwiedzanie gospodarstwa przez E. Gierka ${ }^{38}$, oraz uroczystości dożynkowe zgodne z dotychczasowym schematem. Drugi materiał to przede wszystkim sprawozdanie ze żniw odbywających się na polskiej wsi, a sam I sekretarz pojawia(ł) się w kadrze jedynie podczas zakończenia kroniki ${ }^{39}$.

Kolejny rok to apogeum relacji z uroczystości dożynkowych, w których uczestniczył Edward Gierek, ponieważ było ich aż trzy. Najprawdopodobniej tak częsty udział miał związek z XXX-leciem PRL, któremu to wydarzeniu podporządkowano inne obchody. Pierwsza z nich to obszerna relacja ze żniw, a I sekretarz pojawił się jedynie podczas przybycia na pole i otrzymania chleba od gospodarzy ${ }^{40}$. Następna przedstawiała E. Gierka w czasie doglądania prac polowych, a konkretnie podczas przyglądania się ziemniakom ${ }^{41}$.

\footnotetext{
36 Lista montażowa PKF 36B/71.

37 Lista montażowa PKF 36A/72.

38 Lista montażowa PKF 36A/73.

39 Lista montażowa PKF 39A/73.

40 Lista montażowa PKF 29AB/74.

41 Lista montażowa PKF 37B/74.
} 
W kolejnym ujęciu złożył wizytę gospodarzom dożynek, którzy serdecznie go powitali i wręczyli chleb oraz smalec. Na końcu materiału dekorował sztandar oraz rolników, po czym znów otrzymał chleb.

Kronika 42A/74 była podsumowaniem obchodów dożynkowych. Około drugiej minuty pojawił się I sekretarz, który podszedł do gospodarzy dożynek i odebrał od nich chleb, z którym oczywiście obchodził się z należytym szacunkiem. Komentarz lektora:

Dziękując polskim rolnikom, Edward Gierek zapewnił, że partia i władze państwowe będą dzielić ten chleb sprawiedliwie, tak by starczyło go dla wszystkich Polaków ${ }^{42}$,

miał zapewne wzbudzić zaufanie w stosunku do I sekretarza, którego przedstawiono jako dobrego gospodarza. W kolejnych ujęciach pokazany był w krótkich migawkach podczas oglądania uroczystości, cała uwaga skupiała się na gospodarzach - ludności wiejskiej. Na końcu wraz z ekipą rządzącą podszedł do uczestników i gratulował występu ${ }^{43}$.

W latach 1975-1978 udział E. Gierka w uroczystościach dożynkowych pokazany w PKF nie różnił się zbytnio od tego z lat wcześniejszych. Przedstawiano go podczas przekazania chleba przez gospodarzy i w migawkach $\mathrm{w}$ trakcie oglądania pokazu artystycznego ${ }^{44}$.

Ostatnia tego typu relacja z obecnym I sekretarzem miała miejsce w 1979 r. Tym razem oprócz schematu przytoczono w całości jego przemówienie, co mogło być związane z klęską nieurodzaju jaka dotknęła kraj. Podkreślił to lektor słowami Plony $w$ tym roku mniejsze. Mrozy i powodzie wyrządziły $w$ zasiewach szkody ${ }^{45}$.

Jedną z ważnych uroczystości państwowych „dekady Gierka” były obchody XXX rocznicy powstania Ludowego Wojska Polskiego, podczas których pojawił się przywódca partii. Przedstawiono je w dwóch kronikach. Pierwsza z nich miała charakter bardziej elitarny. Wiązała się z nadaniem wyższych stopni oficerskich i wręczeniem odznaczeń państwowych. E. Gierka przedstawiono podczas wchodzenia do sali wraz z premierem P. Jaroszewiczem i przewodniczącym Rady Państwa H. Jabłońskim wśród oklasków wojskowych. Następnie witał się z oficerami, wręczał nominacje i odznaczenia. Szczególnie podkreślono awans na stopień generała armii W. Jaruzelskiego. E. Gierek został przedstawiony podczas odczytania aktu nominacji i krótkiej rozmowy, sprawiającej wrażenie przyjacielskiej. Następnie wręczano

\footnotetext{
${ }^{42}$ Lista montażowa PKF 42A/74.

${ }^{43}$ Ibidem.

${ }^{44}$ Lista montażowa PKF 37A/75, 38B/76, 37A/78.

${ }^{45}$ Lista montażowa PKF 37A/79.
} 
kolejne awanse. $\mathrm{W}$ odrzutach $\mathrm{z}$ tej kroniki znajdują się materiały z części przemów, toastu z oficerami i co bardziej interesujące, serdeczne przywitanie I sekretarza z Mieczysławem Moczarem ${ }^{46}$.

Drugi materiał związany z tymi obchodami nosi nazwę $W X X X$ rocznicę ${ }^{47}$. Znaczną część stanowiły fragmenty przedstawiające Ludowe Wojsko Polskie. Gierka przedstawiono podczas przemowy okolicznościowej, w trakcie której występowały liczne najazdy na zgromadzoną tłumnie ludność. Odbyła się defilada, a I sekretarz pojawił się na trybunie honorowej. Po uroczystościach miała miejsce wizyta w I Warszawskiej Dywizji Zmechanizowanej, podczas której E. Gierek oglądał sprzęt wojskowy ${ }^{48}$.

Ważny charakter miały rocznice z okazji Dnia Zwycięstwa, które w PKF pojawiały się nieregularnie od 1975 do 1979 r. Trzydziesta rocznica zakończenia II wojny światowej miała najbardziej uroczysty charakter i składała się z relacji z sesji sejmowej, podczas której długą przemowę wygłosił E. Gierek. Następnie przedstawiono defiladę i dekorację sztandarów przez I sekretarza ${ }^{49}$. Kroniki z dwóch kolejnych lat różniły się nieznacznie od tego schematu. Jedynie materiał z 1979 r. miał w większym stopniu charakter wspomnieniowy. Oprócz nagrań archiwalnych przedstawiających II wojnę światową pojawiali się weterani polscy i radzieccy, do których przemawiał I sekretarz ${ }^{50}$.

Gierek brał udział także w innych uroczystościach rocznicowych. Jedną z nich były obchody związane z pięćdziesiątą rocznicą III powstania śląskiego. I sekretarza przedstawiono urywkowo podczas apelu pamięci, wejścia na salę wraz z powitaniem, a następnie w trakcie uroczystości ${ }^{51}$. Myślę, że niebagatelny wpływ na przedstawienie relacji w PKF miał fakt pochodzenia E. Gierka z tego regionu.

Kolejny materiał wiązał się z XXV rocznicą powstania Związku Bojowników o Wolność i Demokrację. Znaczną jego część stanowiło przemówienie I sekretarza, które było w pełni transmitowane. $\mathrm{W}$ jej trakcie pojawiały się najazdy na zebranych gości ${ }^{52}$.

Trzydziesta rocznica wyzwolenia obozu Auschwitz również została przedstawiona w PKF. Materiał filmowy, który nosił tytuł Wieczne ostrzeżenie ${ }^{53}$

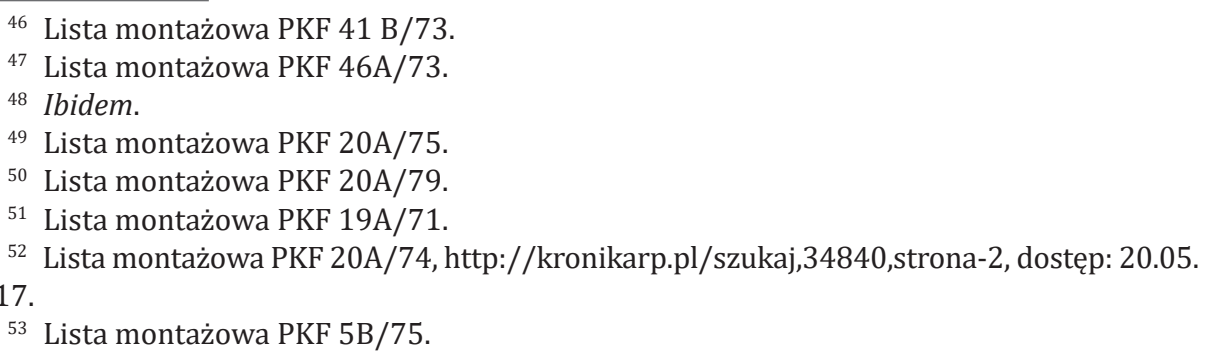

${ }^{46}$ Lista montażowa PKF $41 \mathrm{~B} / 73$.

47 Lista montażowa PKF 46A/73.

48 Ibidem.

49 Lista montażowa PKF 20A/75.

50 Lista montażowa PKF 20A/79.

${ }^{51}$ Lista montażowa PKF 19A/71.

${ }^{52}$ Lista montażowa PKF 20A/74, http://kronikarp.pl/szukaj,34840,strona-2, dostęp: 20.05.

${ }^{53}$ Lista montażowa PKF 5B/75. 2017. 
w znacznej mierze pokazywał fragmenty archiwalne dotyczące obozu i jego wyzwolenia. Gierek pojawił się podczas powitania z byłymi więźniami, a także w trakcie przemowy, którą w skrócie przybliżył lektor ${ }^{54}$. W tym czasie miały miejsce najazdy kamery na słuchających uczestników. Całość zakończyły materiały historyczne i ostrzeżenie lektora, przed możliwym powtórzeniem tych wydarzeń.

W 1979 r. w związku z 40-tą rocznicą wybuchu II wojny światowej w kronice wyemitowano materiał z uroczystości. Miał on w większości wymiar historyczny i I sekretarza przedstawiono w trakcie składania wieńców pod Grobem Nieznanego Żołnierza i później podczas odwiedzin w szkole orląt ${ }^{55}$.

\section{Edward Gierek a partia}

Gierek pełnił nie tylko de facto rolę głowy państwa w PRL-u ${ }^{56}$, lecz był przede wszystkim I sekretarzem KC PZPR, co wiązało się z wieloma obowiązkami. Miały one związek z wystąpieniami publicznymi, a zatem często pojawiały się w PKF. Możemy wyszczególnić kilka kategorii materiałów z nimi związanych, które powtarzają się w kronice. Są to relacje z m.in.:

- zjazdów partii;

- plenów;

- wyborów i posiedzeń sejmu";

- zebrań aktywu i konferencji partyjnych;

- czynów partyjnych.

Pierwszy materiał PKF, w jakim pojawił się E. Gierek po objęciu stanowiska I sekretarza KC PZPR przedstawiał nową władzę szerszej publiczności i ukazał się po świętach Bożego Narodzenia. Składał się on z urywków z wcześniejszych kronik. Lektor podkreślał szczególne związki I sekretarza KC ze Śląskiem, a także górnictwem ${ }^{58}$. Nie powinno to dziwić, ponieważ

54 Ibidem.

55 Lista montażowa PKF 36B/79.

56 W PRL-u formalną głową państwa była Rada Państwa, spośród której Przewodniczący pełnił funkcje reprezentacyjne. W rzeczywistości jednak dużo większe znaczenie miał I sekretarz KC PZPR, ponieważ właśnie tam znajdował się główny ośrodek władzy. Podział ten rodził wiele trudności natury formalnej i protokolarnej. Być może w odpowiedzi na nie E. Gierek został członkiem Rady Państwa od 1976 r. Duże znaczenie w tym kontekście mają zapisy z dzienników J. Tejchmy i M.F. Rakowskiego, które wskazują, że I sekretarz KC PZPR poważnie rozważał możliwość utworzenia stanowiska prezydenta PRL-u, które miał objąć.

57 W kilku kronikach obecność I sekretarza np. w ławach sejmowych jest jedynie zaznaczona. Są to m.in. PKF 7A/71, 51B/71, PKF 42A/73, 22B/75.

58 Lista montażowa PKF 51A/70. 
pełnił on w tamtym regionie funkcję I sekretarza $\mathrm{KW}^{59}$. Zaznaczono jego członkostwo w partii i zajmowane dotychczas stanowiska. Materiał miał zapewne za zadanie przybliżyć sylwetkę nowego przywódcy szerszej publiczności, choć przedstawiał go jako popularnego w całym kraju ${ }^{60}$.

Nowy przywódca PZPR pojawił się również w kolejnej kronice, w materiale Doniosłe decyzje ${ }^{61}$. Tytuł wydaje się wskazywać na znaczenie zmian w kierownictwie partii. Gierek został przedstawiony w czasie przemówienia i rozmów w kuluarach.

\section{Zjazdy PZPR}

Ważnym wydarzeniem związanym z partią, które można było wykorzystać propagandowo były Zjazdy PZPR. Za czasów Gierka odbyły się trzy, z których relacje umieszczono $w$ PKF.

VI Zjazd PZPR został przedstawiony w obszernym materiale o podwójnej numeracji 49B-50A/71. Główne obrady odbywały się w Sali Kongresowej PKiN. Na początku kroniki przedstawiono E. Gierka w czasie przemowy. Szczególny wydźwięk miały wypowiedziane przez niego słowa:

nasz obecny Zjazd przygotowała cała nasza Partia, wszystkie jej organizacje; wielki wkład do prac przygotowawczych wnieśli bezpartyjni robotnicy, chłopi i inteligencja. Nasza Ojczyzna, Polska Ludowa wkracza w nowy etap rozwoju ekonomicznego ${ }^{62}$.

Wskazywały one na próbę budowy szerokiego frontu poparcia wobec polityki partii, która wsłuchuje się w potrzeby i sugestie wszystkich obywateli. Podkreślenie zmian gospodarczych mogło być odcięciem od poprzedniej ekipy, a także przedstawieniem zainteresowania nowych władz potrzebami obywateli. W przemówieniu pojawiały się wątki dotyczące przyszłości młodzieży, które sprytnie wciągnięto w motyw współpracy z ZSRR. Mowę kilkukrotnie przerywały oklaski zgromadzonych, wówczas pojawiały się najazdy kamery na salę. Następnie głos zabrał L. Breżniew, którego jak podkreślił lektor, witano niezwykle serdecznie, co świadczyło zapewne o pozytywnym nastawieniu społeczeństwa polskiego do gościa ze wschodu. Następnie głos zabrał Gustaw Husak - sekretarz generalny Komunistycznej Partii Czechosłowacji i Erich Honecker - sekretarz generalny Socjalistycznej Partii Jedności Niemiec. Kolejność przemów mogła wskazywać na pewną hierarchię

\footnotetext{
${ }^{59}$ P. Gajdziński, Gierek: człowiek z węgla, Poznań 2014, s. 7.

${ }^{60}$ M. Cieśliński, op. cit., s. 115.

${ }^{61}$ Lista montażowa PKF 52AB/70.

${ }^{62}$ Lista montażowa PKF 49B-50A/71.
} 
w bloku wschodnim i podkreślać rolę gospodarza. Ujęcie, w którym przywódca Czechosłowacji ściskał dłoń E. Gierka, wzmacniało natomiast znaczenie relacji między sąsiadami ${ }^{63}$.

Silnie podkreślono pracę dziennikarzy, którzy zrobili niemal wszystko, żebyśmy niemal osobiście uczestniczyli w tym co działo się na sali obrad ${ }^{64}$, co świadczyło o randze zjazdu w państwie. Zaznaczono obecność 250 dziennikarzy z 30 krajów, wśród których szerokim echem odbiła się rezolucja w sprawie Bezpieczeństwa i Współpracy w Europie, mająca świadczyć o pokojowych zamiarach PZPR. Kolejnym mówcą był premier P. Jaroszewicz, po nim zaś przedstawiciele Frontu Jedności Narodu. Podkreślenie tej organizacji mogło wpisywać się w kampanię przed wyborami w 1972 r. Poruszono zagadnienia wzrostu stopy życiowej, warunków socjalnych i budownictwa. W tym samym czasie pojawiły się ujęcia przez przemawiających na Józefa Cyrankiewicza ${ }^{65}$, co mogło być złośliwością skierowaną wobec wcześniejszej ekipy. W późniejszej części przedstawiono serdeczne rozmowy delegatów z E. Gierkiem, P. Jaroszewiczem i L. Breżniewem, co miało zapewne pokazać ich łączność ze społeczeństwami oraz wsłuchiwanie się w problemy ludności. Sielankowy obraz mogło podkreślić wspólne pozowanie do pamiątkowego zdjęcia. Pod koniec materiału znów pojawiła się przemowa E. Gierka przeplatana oklaskami z sali, całość zaś zakończyła „Międzynarodówka”.

Materiał z VII Zjazdu PZPR stanowił najważniejszą część kroniki z grudnia 1975 r. Rozpoczął się ujęciami na klaszczących delegatów, co mogło świadczyć o zadowoleniu i poparciu dla działań partii. W kolejnych przedstawiono najważniejszych uczestników - E. Gierka i L. Breżniewa, którzy zostali podjęci brawami. Główną część materiału stanowiła w pełni przytoczona przemowa I sekretarza PZPR, bez ujęć na salę. Zakończyły ją oklaski połączone z komentarzem lektora: dla Edwarda Gierka - przywódcy partii i narodu, gorace owacje zjazdu ${ }^{66}$. Wówczas pojawiły się kadry ze zgromadzonymi na sali ${ }^{67}, w$ tym z L. Breżniewem, który mógł sprawiać wrażenie pijanego ${ }^{68}$. Z przytoczonego cytatu można wyciągnąć wniosek, że E. Gierek był już nie tyle I sekretarzem, a przewodnikiem całego narodu. Następny materiał kroniki związany był z budową Dworca Centralnego, który stał się symbolem przyśpieszenia ${ }^{69}$. Znów pojawiło się hasło „dobrej roboty”. Wyda-

${ }^{63}$ Ibidem.

${ }^{64}$ Ibidem.

${ }^{65}$ Ibidem.

${ }^{66}$ Lista montażowa PKF 50B/75.

${ }^{67}$ Ibidem.

${ }^{68}$ To właśnie na tym zjeździe L. Breżniew „dyrygował” zebranymi, którzy śpiewali „Międzynarodówkę". Być może znajdował się on pod wpływem silnych leków. J. Rolicki, op. cit., s. 93.

${ }^{69}$ Lista montażowa PKF 50B/75. 
rzenie to wpisano w zjazd partii i miało być widocznym znakiem sukcesów ekipy gierkowskiej, na co wskazywały tłumy obecne podczas uroczystego otwarcia. Interesującym było zaznaczenie placówek handlowo-usługowych w nowopowstałym obiekcie. Być może pokazano w ten sposób zainteresowanie kierownictwa bieżącymi problemami społeczeństwa. Brak szerszej relacji z samego zjazdu mógł być spowodowany wspomnianym już ekscesem L. Breżniewa, którego ze względów propagandowych nie pokazano w PKF.

VIII Zjazd PZPR został przedstawiony w aż trzech kronikach. Być może miało to związek ze słabnącym poparciem dla partii, kryzysem gospodarczym i narastającymi problemami społecznymi. Wydaje się, że wzmożona propaganda miałaby na celu przekonanie obywateli o dokonujących się w Polsce zmianach, rozwoju gospodarczym oraz chęci działania wewnątrz PZPR.

Materiały kroniki szczegółowo pokazywały przebieg zjazdu. Pierwszy stanowił wprowadzenie - znajdowały się w nim ujęcia od powitania delegacji zagranicznych na lotnisku, poprzez przedstawienie wnętrz Pałacu Kultury i Nauki, gdzie odbywały się główne uroczystości, aż do zaprezentowania uczestników. Najważniejszą częścią materiału była w pełni przytoczona przemowa E. Gierka ${ }^{70}$, podczas której pojawiały się ujęcia na salę, delegatów, prezydium, a także na pierwszego polskiego kosmonautę Mirosława Hermaszewskiego. Zaznaczenie jego udziału - postaci niezwykle popularnej - miało zapewne pokazać poparcie dla działań partii, a także pośrednio wskazać na rozwój kraju pod jej skrzydłami. Poprzez pokazanie idola przy E. Gierku próbowano ratować słabnący wizerunek przywódcy PRL-u.

Kolejna kronika, w której był zawarty materiał ze zjazdu, w mniejszym stopniu eksponowała postać I sekretarza. Przedstawiono ją w trakcie krótkiego przemówienia, którego tekst przytoczył lektor, a także podczas podpisywania książek bądź swoich fotografii ${ }^{71}$. Taka scena pojawiła się w PKF po raz pierwszy i być może miała pokazać, że towarzysz Edward cieszy się niesłabnącą popularnością w kraju. W odrzutach znajdują się ujęcia z obrad, podpisywania fotografii i oklasków.

Ostatni materiał zjazdowy, zatytułowany podobnie jak poprzednie, VIII Zjazd Partii ${ }^{72}$ stanowił podsumowanie pięciu dni obrad. E. Gierek został przedstawiony w czasie długiej przemowy kończącej zjazd. Ostatnie ujęcia I sekretarza podczas przyjmowania gratulacji i kwiatów, miały zapewne przedstawić VIII Zjazd jako jego sukces.

\footnotetext{
${ }^{70}$ Lista montażowa PKF 7A/80.

71 Lista montażowa PKF 7B/80.

${ }^{72}$ Lista montażowa PKF 8A/80.
} 


\section{Plena}

W materiałach związanych z działalnością partyjną E. Gierek najczęściej pojawiał się jako uczestnik zgromadzeń plenarnych KC PZPR. Były one $\mathrm{z}$ reguły zwięzłe i prezentowały najważniejsze wydarzenia omawiane $\mathrm{w} \mathrm{KC}$. Z powodu krótkiej relacji z ich przebiegu I sekretarz był ukazany w czasie wygłaszania referatu bądź przemówienia nt. poruszanych na plenum zagadnień, którymi były np. budownictwo mieszkaniowe ${ }^{73}$, sprawy młodzieży ${ }^{74}$, czy zaopatrzenia sklepów ${ }^{75}$. Przywódcę partii często pokazano podczas wchodzenia na salę obrad, co dynamizowało relację. Mogło to także świadczyć o braku czasu, a tym samym dużym zaangażowaniu w sprawy istotne dla kraju. Z racji zajmowanego stanowiska przemawiał jako pierwszy, po nim zaś inni zebrani, niekiedy pojawiał się w podsumowaniu. $\mathrm{W}$ drugim przypadku przedstawiano całą przemowę, którą dynamizowano przez ujęcia na salę, bądź poszczególnych zgromadzonych. Ciekawa była relacja z XVI Plenum z 1975 r., zawierająca dwie przemowy E. Gierka pasujące do obydwu opisanych przeze mnie schematów ${ }^{76}$. W materiałach z plenów pojawiały się krótkie nagrania wypowiedzi innych osób, co również dynamizowało przekaz, a także sprawiało wrażenie szerokiej dyskusji i szczegółowego omówienia przedstawionych tematów. Jednocześnie było to zaprzeczenie prawdziwego obrazu tych obrad, ponieważ po początkowej zmianie ich charakteru, już od połowy 1971 r. zaczęły przypominać te sprzed Grudnia '70. Były monotonne i mało ciekawe, a do tego poruszano na nich kwestie, którymi zająć się mogły inne organy ${ }^{77}$.

W relacji z VIII Plenum z lutego 1971 r. przytoczono pełną przemowę E. Gierka. W czasie jej trwania pojawiały się ujęcia sali, poszczególnych uczestników, przejazd kamery od przemawiającego na zgromadzonych, a także kadry z I sekretarzem ${ }^{78}$. Zabiegi te zwiększały atrakcyjność materiału i ukazywały zainteresowanie zebranych. Odmienna i obszerniejsza relacja, być może miała związek ze zmianą władzy w państwie i sytuacją na wybrzeżu ${ }^{79}$. Jej celem było przekazanie planów nowej ekipy, pokazanie

${ }^{73}$ http://kronikarp.pl/szukaj,34274,strona-3, dostęp: 23.04.2017.

${ }^{74}$ Podkreślono również jej szczególną rolę i szerokie konsultacje społeczne. http://kronikarp.pl/szukaj,32446,strona-2, dostęp: 23.04.2017; Lista montażowa PKF 48A/72.

${ }^{75}$ http://kronikarp.pl/szukaj,34274,strona-3, dostęp: 23.04.2017.

76 Lista montażowa PKF 2B/75.

77 J. Tejchma, Odszedł Gomułka, przyszedł Gierek: notatki z lat 1971-1973, Toruń 2006, s. 108.

78 http://kronikarp.pl/szukaj,1582,strona-2, dostęp: 23.04.2017; Lista montażowa PKF 6A/71.

${ }^{79}$ Głównym celem ekipy na przełomie 1970 i $1971 \mathrm{r}$. była pacyfikacja nastrojów społecznych. J. Eisler, op. cit., s. 277. 
dążeń do szybkiego rozwiązania zaistniałych problemów, a także przedstawienie E. Gierka szerszej publiczności.

Kolejny materiał, tym razem z IX Plenum powiększony był o wręczanie odznaczeń zasłużonym, ze szczególnym uwzględnieniem powstańców śląskich ${ }^{80}$, co mogło wiązać się z uroczystościami rocznicowymi, które ze względu na zainteresowanie E. Gierka tym regionem nabrało poważniejszego znaczenia.

Relacja z IX Plenum z 1973 r. ukazała się natomiast jako drugi materiał po przekazie spotkania Nixon - Breżniew, co świadczyć mogło o eksponowaniu ważnych wydarzeń międzynarodowych w kronice. Wzbogacono ją o moment wejścia E. Gierka na salę obrad i powitania z H. Jabłońskim ${ }^{81}$.

Materiał z XVIII Plenum z 1975 r. nie odbiega od utartego, krótkiego schematu, wzbogacony był o ujęcie notującego I sekretarza ${ }^{82}$, co mogło świadczyć o zainteresowaniu referowanymi sprawami i zapracowaniu.

Interesującym jest fakt zaprzestania umieszczania relacji z plenów od 1977 r. Mogło to mieć związek z dominującą pozycją telewizji, która stawała się coraz bardziej powszechnym medium i w przeciwieństwie do PKF była w stanie na bieżąco relacjonować istotne (przynajmniej dla władz) wydarzenia $^{83}$. Z drugiej zaś strony, być może w perspektywie powiększających się problemów gospodarczych zadecydowano o zmniejszeniu liczby drażliwych tematów? Częste umieszczanie relacji z plenów w początkach dekady Gierka mogło wskazywać na jego aktywny udział w sprawach ważnych dla kraju i podejmowaniu na forum publicznym ważnych problemów społecznych.

\section{Wybory}

PZPR jako uczestnik systemu demokracji socjalistycznej ${ }^{84}$ stanowiła główną i przewodnią ${ }^{85}$ siłę polityczną kraju, w związku z czym brała udział w wyborach. Tym samym prowadziła kampanie wyborcze, agitowała do wstępowania $w$ jej szeregi uczestniczyła $w$ obradach sejmu. Funkcjonowała w podporządkowanym jej FJN. E. Gierek jako I sekretarz brał udział w tych wydarzeniach, te zaś gościły w PKF.

${ }^{80}$ Lista montażowa PKF 15A/71.

${ }^{81}$ Lista montażowa PKF 26A/73.

${ }^{82}$ Lista montażowa PKF 36B/73.

${ }_{83}$ M. Cieśliński, op. cit., s. 119-120.

${ }^{84}$ L. Habuda, Rządzący rządzeni: Totalitaryzm w stosunkach władzy w PRL, Opole 2001, s. 110

${ }^{85}$ J. Wielgosz, Kierownicza rola PZPR wobec państwa i społeczeństwa socjalistycznego, Kraków 1971, s. 3. 
Pierwszy materiał związany z wyborami odbywającymi się w 1972 r., a w którym pojawił się E. Gierek nosił tytuł Program wyborczy ${ }^{86}$. Przedstawiał idących delegatów, wśród których obecny był I sekretarz w towarzystwie prof. Janusza Groszkowskiego z FJN. Pojawienie się tych dwóch osób razem, w kontekście późniejszego wyboru profesora na przewodniczącego FJN mógł świadczyć o przedwyborczym lansowaniu swojego kandydata.

Następny materiał został zatytułowany Kampania wyborcza ${ }^{87}$. Przedstawiał tłumy ludzi idące na wiec, zebranych oraz przemawiającego E. Gierka, którego wystąpienie zostało przytoczone przez lektora. Szczególnie ważny wydaje się cytat: wszystkie siły odda $w$ sprawie socjalistycznej ojczyzny ${ }^{88}$, sugerujący, że I sekretarz dołoży wszelkich starań, by kraj mógł się jak najprężniej rozwijać. Jednocześnie mógł stanowić uderzenie w poprzednią, najwyraźniej zbyt mało zaangażowaną ekipę rządzącą. Materiał kończyło ujęcie na zgromadzonych i oklaski dla przywódcy partii.

Ostatnia kronika związana z tymi wyborami zawierała moment głosowania w różnych częściach Polski. Jako pierwszy został przedstawiony I sekretarz wraz z małżonką w czasie wejścia do lokalu wyborczego, rutynowych czynności związanych z przygotowaniem do głosowania i podczas wrzucenia wspólnie z żoną karty do urny. W dalszej części materiału pojawiały się inne postaci, pochodzące z różnych grup społecznych, które oddały swój głos ${ }^{89}$. E. Gierek sprawiał wrażenie zwykłego mieszkańca, spełniającego swój obywatelski obowiązek. Jednak gdy zobaczy się materiały z odrzutów, można odnieść wrażenie, że to tylko specjalna kreacja. Znajdują się w nich bowiem ujęcia, przedstawiające przywódcę partii podczas powitania z członkami komisji, a po oddaniu głosu wręczenie mu kwiatów. Świadczy to ewidentnie o specjalnym traktowaniu tego wyborcy. Usunięcie ich mogło wskazywać, że I sekretarz jest takim samym obywatelem jak reszta społeczeństwa.

$\mathrm{W}$ niedługim czasie ukazały się $\mathrm{w}$ dwóch kronikach materiały powyborcze. Pierwszy, zatytułowany I sesja ${ }^{90}$ dotyczył sejmu i przedstawiono w nim dokonane zmiany na stanowiskach. Ważną wydaje się być przemowa I sekretarza, w której dziękował rodakom za zaszczytne zaufanie jakim obdarzyli nas $w$ głosowaniu powszechnym ${ }^{91}$. Ten przekaz wydawał się być ukłonem w stronę społeczeństwa, wskazując na jego znaczenie i siłę. Mógł być także próbą wzmocnienia znaczenia wyborów. E. Gierek został także uchwycony w czasie uważnego słuchania orędzia nowego premiera P. Jaroszewicza.

\footnotetext{
${ }^{86}$ Lista montażowa PKF 5A/72.

87 Lista montażowa PKF 8B/72.

88 Ibidem.

${ }^{89}$ Lista montażowa PKF 12A/72.

${ }^{90}$ Lista montażowa PKF 13B/72.

${ }^{91}$ Ibidem.
} 
W drugim materiale noszącym tytuł Sesja OKFJN ${ }^{92}$ obecność I sekretarza została jedynie zaznaczona. Przekaz był jednak podobny do przemowy E. Gierka z I sesji. Zaznaczono obecność przedstawicieli wszystkich grup społeczeństwa (obrazując to m.in. duchownym obrządku wschodniego), przedstawiono cel co możemy zrobić, aby żyło nam się lepiej ${ }^{93}$ i zaznaczono, że rozpoczął się czas realizacji postulatów. Przekaz kroniki mógł sprawiać wrażenie próby budowania społeczeństwa obywatelskiego w ramach PRL-u i to pod egidą I sekretarza.

Ciekawą uwagę skierowaną wobec tych wyborów można znaleźć w „Dziennikach politycznych” Mieczysława F. Rakowskiego. Wskazywał on, że mimo zapowiedzi zmian $\mathrm{w}$ ordynacji wyborczej i szerszego spojrzenia na pulę kandydatów, które miało zatrzeć zaistniałe podziały nie podjęto ku temu żadnych kroków ${ }^{94}$. Wyjaśnia to poniekąd szeroką kampanię propagandową przed i po głosowaniu próbującą przekonać obywateli do rzekomej zmiany podejścia władzy do wyborów.

Kolejny materiał PKF związany z sejmem i E. Gierkiem został zatytułowany Sejmowe obrady ${ }^{95}$ i miał związek z Barbórką. Górnicy złożyli wizytę I sekretarzowi w gmachu parlamentu, ten zaś witał się z nimi, rozmawiał i składał życzenia. Ich spotkanie w kontekście życiorysu E. Gierka nie powinno dziwić. Wizyta tej grupy zawodowej mogła być także swego rodzaju nobilitacją dla społeczności górniczej.

W pierwszej kronice 1973 r. zatytułowanej Czas przemian ${ }^{96}$ nastąpiło podsumowanie minionego roku. Zaznaczono wybory do sejmu, a w materiale pojawił się I sekretarz wrzucający głos do urny. To samo uczyniły według przekazu kroniki zarówno osoby starsze jak i młodsze, górnicy, a nawet zakonnik.

W 1976 r. materiał związany z wyborami nie był już tak bardzo eksponowany jak przed czterema laty. Ujęcia Gierka głosującego wraz z żoną pojawiały się po wcześniejszej relacji z przemówienia I sekretarza. Po oddaniu głosu jego małżonka otrzymała kwiaty od komisji ${ }^{97}$. Być może u szczytu sukcesów nie trzeba było zwracać się w stronę społeczeństwa i zaprzestano prób wzbudzania zaufania społecznego? Relacja z wyborów mogła wręcz świadczyć o arogancji władzy w stosunku do obywateli.

${ }_{92}$ Lista montażowa PKF 14B/72, http://www.repozytorium.fn.org.pl/?q=pl/node/9636, dostęp: 24.04.2017.

${ }_{93}$ Ibidem.

${ }_{94}$ M. Rakowski, op. cit., s. 21-33.

${ }_{95}$ Lista montażowa PKF 48B/72.

${ }_{96}$ https://www.youtube.com/watch?v=1DEpSzygcMU\&list=PL9FF6C55341DB4BF6, dostęp: 23.04.2017.

${ }^{97}$ Lista montażowa PKF 13A/76. 
Około tygodnia później pojawił się materiał z rozpoczęcia posiedzenia Sejmu VII Kadencji. Przywódca PZPR został ukazany w czasie wysłuchiwania przemówienia z okazji otwarcia obrad przez Jarosława Iwaszkiewicza, następnie podczas w pełni przytoczonej przemowy z najazdami na słuchają$\operatorname{cych}^{98}$. Na zakończenie materiału został przedstawiony wraz z Radą Państwa.

Po opisanych już przeze mnie wcześniej relacjach z VIII Zjazdu pojawiły się materiały związane z wyborami przypadającymi na 1980 r. Materiał Obrady sejmu $^{99}$ ukazał I sekretarza w czasie krótkiej przemowy, podczas której przedstawił jako kandydata na premiera Edwarda Babiucha. Po nim nastąpiły ujęcia na posłów, salę i przemówienie nowego prezesa Rady Ministrów.

Kronika bezpośrednio dotycząca wyborów nosiła tytuł Manifestacja jedności $i^{100}$. Takie przedstawienie sprawy miało najprawdopodobniej pokazać silną więź łączącą partię i obywateli PRL-u, a także świadczyć o tym, że kierunki wyznaczane przez PZPR były w pełni akceptowane przez naród. Znów, po ujęciach pokazujących urny i karty do głosowania, przedstawiono E. Gierka. Przybył on wraz z małżonką do lokalu wyborczego, po czym pokazano moment sprawdzenia ich dowodów osobistych i wrzucenia głosów do urny. Być może ze względu na panujące w społeczeństwie zniechęcenie znów wrócono do kreacji I sekretarza jako zwykłego obywatela, spełniającego obowiązek wobec państwa. Po nim pojawił się głosujący Babiuch i Dobrowolski. Głos wrzucało dziecko, warszawiacy, mieszkańcy wsi i zakonnica - te ujęcia znów miały pokazać głosowanie jako zapowiedzianą w tytule manifestację jedności pomiędzy obywatelami i PZPR. Świadczyły o tym również słowa lektora: Wyrażono poparcie dla społeczno-gospodarczego programu rozwoju kraju, szeroko dyskutowanego na spotkaniach przedwyborczych i prasie ${ }^{101}$. Zwiększenie nacisku na wspomniane poparcie, zaznaczenie szerszego udziału i konsultacji (w przeciwieństwie do poprzednich wyborów) mogło być związane z fiaskiem planów gospodarczych, problemami społecznymi i stanowić odpowiedź na swego rodzaju arogancję (władzy) wobec wyborców, jaka pojawiła się cztery lata wcześniej. Rzeczywistość przedwyborcza była jednak diametralnie inna, a opisał ją M.F. Rakowski, twierdząc, że jedyne spotkania jakie odbył wiązały się z aktywem partyjnym, a sama kampania była bardzo ospała ${ }^{102}$.

Ostatnim materiałem związanym z sejmem w którym pojawił się E. Gierek było rozpoczęcie obrad Sejmu VIII kadencji. Najazd kamery na Radę Państwa

\footnotetext{
98 Lista montażowa PKF 14A/76.

99 Lista montażowa PKF 8A/80.

${ }^{100}$ Lista montażowa PKF 13A/80.

101 Ibidem.

102 M. Rakowski, op. cit., s. 165.
} 
przybliżył jego sylwetkę, obok H. Jabłońskiego i E. Babiucha. Po ujęciach na innych posłów lektor przytoczył przemówienie I sekretarza KC. Następnie obył się wybór Rady Państwa i premiera. Co interesujące pod koniec materiału lektor użył sformułowania poseł Edward Gierek ${ }^{103}$. Nasuwa się pytanie dlaczego podkreślono akurat tę funkcję? Być może wiązało się z próbą podkreślenia, w jakiej roli proponował on kandydatów na najważniejsze stanowiska (poseł to kandydat społeczeństwa), oraz że oprócz pełnienia funkcji I sekretarza jest również posłem.

\section{Gierek i aktyw partyjny}

W kronice ze stycznia 1973 r., po materiale z okazji urodzin I sekretarza pojawiła się kronika pt. Obrady aktywu ${ }^{104}$. E. Gierek został ukazany w prezydium, podczas krótkiej przemowy przytoczonej przez lektora. Następnie wystąpił premier mobilizując zebranych w roku kluczowym dla całej pięciolatki $^{105}$. Być może miało to na celu zwarcie szeregów partii. Następnie wystąpili liczni mówcy, którzy potwierdzili, że nowy program społeczno-gospodarczy wyzwolił olbrzymie zasoby energii i inicjatywy, i zaufania w całym społeczeństwie ${ }^{106}$, co mogło świadczyć o słusznej linii nowego kierownictwa, popartej przez społeczeństwo. Całość zakończył przemawiający Gierek i ujęcia na salę, w których uderzają częste najazdy kamery na górników. Ciekawszym spostrzeżeniem wydaje się jednak jednorazowa zmiana sposobu przedstawiania I sekretarza. Zwykle kamera była ustawiona wyżej lub w linii prostej do E. Gierka i z reguły w dalszej odległości od przemawiającego. Tym razem znajdowała się przed uczestnikami, przy samej trybunie i była umieszczona nieco niżej, pod lekkim kątem ${ }^{107}$. Niwelowało to specyficzny i mało atrakcyjny sposób przemów I sekretarza, który czytał wpatrzony w kartkę i co jakiś czas podnosił wysoko głowę ${ }^{108}$. Tym razem z powodu innego ustawienia kamery styl przemowy nie raził oglądających, a wręcz w korzystnym świetle ukazywał postać Gierka. Także przytoczeni tekstu przez lektora, uatrakcyjniało i dynamizowało relację.

W 1973 r. miała miejsce I Krajowa Konferencja PZPR. W kronice pojawił się obszerny materiał z tego wydarzenia. Na samym początku, po kilku

103 Lista montażowa PKF 15A/80.

104 http://kronikarp.pl/szukaj,32490,strona-2, dostęp: 23.04.2017 r.; Lista montażowa PKF 2A/73.

105 Ibidem.

106 Ibidem.

107 http://kronikarp.pl/szukaj,32490,strona-2, dostęp: 23.04.2017.

$108 \mathrm{~W}$ porównaniu z przemówieniami jego poprzednika i tak wypadały relatywnie dobrze. P. Gajdziński, op. cit., s. 7. 
ujęciach na zgromadzonych, lektor podkreślił wyjątkowe sukcesy i dynamikę rozwoju w ciągu ostatnich dwóch lat, w których I sekretarzem był E. Gierek. Zaznaczono jego istotną rolę $w$ zmianach jakie zaszły od przejęcia władzy przez nową ekipę, na co wskazywał cytat: doniosłe wydarzenie w życiu kraju, poprzedzone szeroka dyskusja o stanie rozwoju Polski ${ }^{109}$. Po tym pojawiło się około 2,5 minutowe wystąpienie E. Gierka z kilkoma ogólnymi ujęciami na salę i zbliżenie na ekran drugiej kamery ${ }^{110}$. W następnej kolejności głos zabrał premier w nieco krótszym wystąpieniu, co mogło świadczyć o wewnętrznej hierarchii. Całość zakończyły owacje i ujęcie klaszczących górników.

Interesującą jest natomiast kronika zatytułowana Droga VI Zjazdu ${ }^{111}$. Pojawiła się ona około dwóch tygodni później i również była relacją z I Krajowej Konferencji PZPR. W tym przypadku cały numer podporządkowany był jednemu wydarzeniu i stanowił spójną całość. Na samym początku podkreślono dużą liczbę zgromadzonych - 2 tys. delegatów z wszystkich regionów, a także rolę spotkania - przegląd dotychczasowych osiągnięć i możliwości utrwalenia wysokiego tempa rozwoju kraju. Takie zaznaczenie sprawy, a także wystąpienie E. Gierka mogło przedstawiać I sekretarza jako osobę, dzięki której rozwój kraju stał się pełniejszy. Trwała ona około 4 minut, a mówca został przedstawiony w bliskich i dalszych ujęciach, z częstymi najazdami kamery na zgromadzonych i salę. Gierkowi przemowę przerwała gorąca owacja na stojąco. W późniejszej części materiału trwającej ponad 7 minut przedstawione zostały różne inwestycje podjęte w planie gospodarczym. W trakcie nagrania umieszczono krótkie wystąpienie I sekretarza trwające około jednej minuty ${ }^{112}$. Wydawać się może, że ten monotematyczny ${ }^{113}$ materiał miał za zadanie podkreślić sukcesy rządzącej trzy lata nowej ekipy, mnogość inwestycji a także rozwiązanie problemów i zaniedbań poprzedników.

Początek następnego roku przyniósł materiał pod tytułem Program działania $19744^{114}$. Oprócz przemówienia premiera głos zabrał E. Gierek, jednak widzowie mogli usłyszeć jedynie fragmenty przemowy przytoczone przez lektora. W międzyczasie pojawiały się ujęcia na słuchających. Całość wskazywała na otwartość partii i rządu w stosunku do obywateli, co przejawiało się w informowaniu o planach na najbliższy czas.

109 http://www.kronikarp.pl/szukaj,34796,tag-692104,strona-1, dostęp: 23.04.2017; Lista montażowa PKF 43A/73.

110 Ibidem.

111 Lista montażowa PKF 45A/73, https://www.youtube.com/watch?v=BBOQq-uClJM dostęp: 23.04.2017.

112 Ibidem.

113 Tego typu materiały stały się charakterystyczne dla „dekady Gierka” w PKF, M. Cieśliński, op. cit., s. 122.

114 Lista montażowa PKF 6B/74. 
Kolejny materiał związany z PZPR pojawił się w 1975 r. i nosił tytuł Legitymacja partyjna ${ }^{115}$. I sekretarzowi wręczono wówczas legitymację partyjną z numerem 1 , co mogło być symbolicznym podkreśleniem jego pozycji w PZPR ${ }^{116}$. Następnie wręczał kolejne egzemplarze nowym członkom, po czym nastąpiły przemówienia dygnitarzy. Na zakończenie głos zabrał E. Gierek. Kronika mogła mieć na celu wzmocnienie i podkreślenie roli partii, a także zachęcić do wstępowania w jej szeregi ${ }^{117}$. Być może materiał wpisywał się w szeroki front zmian społecznych dokonywanych w połowie lat siedemdziesiątych, na który składała się reorganizacja organizacji młodzieżowych, reforma edukacji i zmiany w konstytucji.

W związku z wydarzeniami w Ursusie i Radomiu w czerwcu 1976 r. władze partyjne rozpoczęły kampanię propagandową, której celem było wzmocnienie poparcia dla I sekretarza KC ${ }^{118}$. W PKF pojawił się jeden materiał z wiecu poparcia odbywający się w katowickim Spodku, a noszący wymowny tytuł Poparcie polityki partii ${ }^{119}$. Gierek został przedstawiony podczas przybycia na wiec $\mathrm{w}$ towarzystwie premiera P. Jaroszewicza, któremu licznie zgromadzona publiczność sprawiła owacje na stojąco oraz wykrzykiwała jego nazwisko. Lektor komentował sytuację słowami: Wielka manifestacja poparcia dla polityki partii i rządu ${ }^{120}$. Następnie pojawiła się przemowa I sekretarza dotycząca spraw bieżących, polityki gospodarczej i społecznej trwająca około 4 minut. Przedstawiono go podczas intensywnej gestykulacji, sama zaś postać wydaje się bardzo zaangażowana w sprawy o których mówi. Być może był to celowy zabieg mający przekonać odbiorców o silnym oddaniu I sekretarza problemom społecznym, które stały się w tamtym czasie dużym wyzwaniem dla władz. Podczas początkowych słów E. Gierka tłum krzyczał najprawdopodobniej słowa Niech żyje ${ }^{121}$, co zapewne miało wzmocnić przekaz poparcia dla niego. Po wymienieniu w przemowie P. Jaroszewicza nastąpiły oklaski zgromadzonych, co zapewne mogło być próbą rehabilitacji premiera. W trakcie wystąpienia zaznaczono ujęcia na salę i zgromadzonych, którzy reprezentowali róże zawody.

115 Lista montażowa PKF 15A/75.

116 Wręczanie legitymacji miało związek z ich wymianą na nowe egzemplarze.

117 W 1975 r. PKF prowadziła dyskretną akcję promującą wstępowanie do PZPR, M. Cieśliński, op. cit., s. 131-133.

118 J. Eisler, op. cit., s. 292-293.

119 Już samo sformułowanie tematu może wskazywać na silne utożsamianie PZPR z osobą I sekretarza. Lista montażowa PKF 28B/76, http://kronikarp.pl/szukaj,33632,strona-3, dostęp: 23.04.2017; https://www.youtube.com/watch?v=hM2VjRl7QIk, dostęp: 23.04.2017.

120 Ibidem.

121 Ibidem. 
Po zakończeniu nastąpiły owacje na stojąco zgromadzonej publiczności i komentarz lektora: Przemówienie zostało przyjęte z najwyższym zainteresowaniem przez całe społeczeństwo ${ }^{122}$, które miały zapewne podkreślić wymowę tej części kroniki. Podobnie przedstawiała się końcówka materiału, w czasie której E. Gierek wśród oklasków otrzymał kwiaty od kobiety, która następnie go pocałowała. Rozmawiał także z ludźmi uczestniczącymi w wiecu. Podkreślano ujęcia, w czasie których ściskał ręce rozmówcom. Mogło to świadczyć o zainteresowaniu sprawami obywateli ${ }^{123}$, a także o żywym poparciu udzielonym Gierkowi przez społeczeństwo. Sam wybór miejsca wiecu wydaje się być nieprzypadkowy, ponieważ właśnie z tego regionu pochodził, tam piastował wcześniejsze stanowiska i cieszył się dużą popularnością. Kronikę przeznaczono do odtworzenia jedynie w kinach większych miast, co według M. Cieślińskiego było spowodowane brakiem zainteresowania i dezaprobatą na twarzach obecnych ${ }^{124}$. Wydaje mi się jednak, że być może z powodu „miejskiego" charakteru wydarzeń z czerwca 1976 r. podjęto taką decyzję. Być może wpływ na to miał jeden z kolejnych materiałów tej kroniki, który nosił tytuł Ziemia dla rolników ${ }^{125}$. Krytykował on nieudolne zarządzanie w niektórych gospodarstwach spowodowane nadużywaniem alkoholu przez gospodarzy. Naszq ziemiq musza zająć się rolnicy z prawdziwego zdarzenia ${ }^{126}$ - te kontrowersyjne słowa wypowiedziane przez lektora, a zobrazowane sytuacją jednego gospodarstwa w mojej opinii mogły przyczynić się do braku emisji materiału w mniejszych miejscowościach. Jerzy Eisler wskazywał zaś na podobieństwo całości kampanii propagandowej i tego konkretnego wiecu do nagonki antyinteligenckiej i antysemickiej z 1968 r. ${ }^{127}$, co również mogło wpłynąć na ograniczenie emisji.

Po dłuższej przerwie w 1978 r. w PKF pojawił się materiał z II Krajowej Konferencji PZPR. Po panoramie na salę przedstawiono E. Gierka, który rozpoczął obrady swoim przemówieniem. W tym czasie pojawiały się ujęcia na słuchających. Następnie rozpoczęła się dyskusja, po której delegaci ze Śląska wręczyli I sekretarzowi kubełek z pierwszym wydobytym w tym roku węglem ${ }^{128}$. Świadczyć to mogło o oddaniu regionu wobec Gierka. Tą część podsumowały oklaski i rozmowa z delegatami. Następnie pojawiła się dys-

${ }^{122}$ Ibidem. Słowa lektora pośrednio podkreślają, że wiec był transmitowany przez radio i telewizję.

${ }^{123}$ E. Gierek, Smak życia. Pamiętniki, Warszawa 1993, s. 93.

${ }_{124}$ M. Cieśliński, op. cit., Warszawa 2006, s. 135.

125 https://www.youtube.com/watch?v=hM2VjRl7QIk, dostęp: 23.04.2017.

126 Ibidem.

127 J. Eisler, op. cit., s. 294.

${ }^{128}$ Lista montażowa PKF 2B/78. 
kusja i przemowy innych uczestników, które zakończyło krótkie wystąpienie I sekretarza. Wobec kryzysu gospodarczego nie dziwi krótsza relacja w stosunku do I Krajowej Konferencji PZPR.

W początkach 1976 r. E. Gierek brał udział w VII Kongresie Zjednoczonego Stronnictwa Ludowego ${ }^{129}$, które było partią satelicką wobec PZPR. Został przedstawiony podczas przybycia na obrady, a także $w$ trakcie krótkiej przemowy, co mogło podkreślić znaczenie partii satelickiej.

I sekretarz pojawiał się w materiałach związanych z „czynami partyjnymi”. Był przedstawiany w kronice z 1974, 1975, 1976, 1977 i 1980 r. podczas lekkich prac polowych, w czasie których towarzyszyła mu małżonka. W relacjach podkreślano łączność w pracy wszystkich środowisk, która mogła się skupiać wokół osoby I sekretarza. Natomiast w latach 1973, 1978 i 1979 jego postać znalazła się w odrzutach. Zwiększona obecność I sekretarza od 1974 r. mogła wiązać się z chęcią wzmocnienia kontroli współzawodnictwa pracy przez partię ${ }^{130}$. Wpisywała się również idealnie w próby wzrostu wydajności pracy lansowane przez gierkowską ekipę ${ }^{131}$.

\section{Edward Gierek wśród społeczeństwa}

Przywódca PZPR pojawiał się także w innych materiałach wśród znanych i popularnych wówczas czasach osób oraz pośród młodzieży. Być może celem takiego działania było podkreślenie poparcia skierowane ku niemu przez wspomnianych, a co za tym idzie zwiększenie jego popularność. Z drugiej zaś strony wskazywało na zainteresowanie kulturą, nauką i sportem.

Z okazji osiemdziesiątych urodzin J. Iwaszkiewicza w PKF pojawił się materiał zatytułowany Twórca i działacz ${ }^{132}$. W kronice pojawił się, być może ze względu na zasiadanie poety w sejmie, E. Gierek z żoną podczas rozmowy z Iwaszkiewiczami. Wskazywało to na zainteresowanie I sekretarza sprawami kultury, a także sprawiło sielskie wrażenie. W późniejszej części nagrania wręczył poecie Order Odrodzenia Polski ${ }^{133}$. Materiał wydawał się być ukłonem w stronę środowisk bezpartyjnych, zaangażowanych w rozwój Polski Ludowej ${ }^{134}$.

129 Lista montażowa PKF 4B/76.

130 M. Zaremba, Komunizm jako system mobilizacyjny - casus polski, [w:] Komunizm: ideologia, system, ludzie, Warszawa 2001, s. 123.

131 J. Rolicki, op. cit., Warszawa 1990, s. 74.

132 Lista montażowa PKF 8B/74.

133 Skrót z tego wydarzenia znajduje się również w PKF 11A/80 związanej ze śmiercią Jarosława Iwaszkiewicza

${ }^{134}$ Edward Gierek miał podkreślać aktywność w pracy z bezpartyjnymi, Partia - państwo - społeczeństwo, red. R. Dudek i Z. Siembirowicz, Warszawa 1978, s. 97. 
Zaznaczano życzliwy stosunek przywódcy partii wobec środowisk twórczych. W 1977 r. w kronice pojawił się materiał związany z inauguracją nowego roku akademickiego w łódzkiej filmówce. E. Gierek był obecny wśród przedstawicieli kultury i sztuki podczas koncertu oraz rozmów. Ważne były słowa lektora: kwestie polityki kulturalnej Partia rozstrzyga wspólnie z ludźmi kultury ${ }^{135}$. Zaznaczono jednak, że środki finansowe muszą być dobrze wykorzystane. Nagranie zdaje się przekazywać odmienny stosunek E. Gierka wobec środowisk twórczych w porównaniu do swojego poprzednika. Mogło to być próbą zdobycia ich przychylności.

Nie mogło zabraknąć również materiałów związanych z techniką. W 1971 r. E. Gierek pojawił się na Kongresie Techniki Polskiej. Zaznaczono jego udział w obradach. Ważniejsze wydaje się spotkanie z inżynierami polskiego pochodzenia przybyłymi zza granicy, do których apelował, by wspierali radą i doświadczeniem swoją ojczyznę ${ }^{136}$. Przemowa wskazywała na potrzeby państwa związane z planami gospodarczymi, a także deklarowała pozytywny stosunek do emigrantów.

W kronice zaznaczono zainteresowanie I sekretarza kulturą radziecką, czego przykładem był materiał z 1975 r., w którym pojawił się podczas koncertu inauguracyjnego ${ }^{137}$. Podobny wydźwięk miał materiał z 1977 r., podkreślający przyjazny stosunek ZSRR do Polski. E. Gierek oglądał przekazane z tego państwa dzieła sztuki, militaria i sztandary ${ }^{138}$.

W 1974 r. w PKF pojawił się materiał z powrotu polskich piłkarzy z Mistrzostw Świata w Piłce Nożnej. Próbowano wpisać ich sukces w wydarzenia powiązane $\mathrm{z}$ jubileuszem Polski Ludowej, czego przykładem było zbliżenie na transparent Srebro nam wieziecie na XXX lecie $^{139}$. Podkreślono ogromy entuzjazm tłumów, które przybyły witać sportowców, a jako fanów piłki nożnej kronika podała żartobliwą liczbę 34 mln Polaków. Takiej popularności władze PRL-u nie mogły nie wykorzystać. W późniejszej części materiału przedstawiono spotkanie piłkarzy z E. Gierkiem i P. Jaroszewiczem. Składał się na nie uścisk dłoni z reprezentantami i przemowa I sekretarza, w której podziękował za wspaniały prezent jaki zgotowali naszej socjalistycznej ojczyźnie ${ }^{140}$ piłkarze nazwani „towarzyszami”. Skierował także słowa

135 Lista montażowa PKF 39A/77.

${ }^{136}$ Lista montażowa PKF 36A/71.

137 Lista montażowa PKF 17A/75.

${ }^{138}$ Lista montażowa PKF 31A/77.

139 Polska reprezentacja zdobyła srebro za zajęcie trzeciego miejsca, ponieważ właśnie w 1974 r. wprowadzono cztery komplety medali na Mistrzostwach Świata w Piłce Nożnej http://kronikarp.pl/szukaj,34858,strona-2, dostęp: 23.04.2017; Lista montażowa PKF 28B/74; https://www.youtube.com/watch?v=0JWtcmMG5XQ, dostęp: 23.04.2017; http://www. repozytorium.fn.org.pl/?q=pl/node/5792, dostęp: 23.04.2017.

140 Ibidem. 
do młodzieży, która chcąc może osiagnąć cel, do którego zmierza ${ }^{141}$. Całość zakończył kieliszek szampana ze zgromadzonymi. Sukces reprezentacji, podkreślony przez I sekretarza pokazano jako wzór do naśladowania, próbując zawłaszczyć go do własnych celów, przede wszystkim jako pokazanie łączności obywateli i władz dzięki piłce nożnej.

Kinematografia stanowiła ważny punkt w propagandzie PRL-u, nie dziwi zatem materiał z nią związany umieszczony w PKF. Dotyczył on XXX-lecia kina w Polsce Ludowej. E. Gierek został przedstawiony w czasie wysłuchiwania przemówienia P. Jaroszewicza, a następnie podczas wręczania odznaczeń znanym osobom powiązanym ze światem kina, m.in. Andrzejowi Łapickiemu i Beacie Tyszkiewicz ${ }^{142}$. Materiał mógł być ukłonem w stronę świata filmowego, a wraz z nim podkreśleniem poparcia tego środowiska.

Postać E. Gierka pojawiła się w materiale związanym z XXXV rocznicą powstania PKF. Znalazł się tam jednak tylko podczas wręczania odznaczeń dla osób związanych z kroniką. Co interesujące nagrania te zostały wykopiowane z kroniki PKF 46B/75 ${ }^{143}$. Prawdopodobnie materiał miał podkreślać rolę twórców PKF, zaś I sekretarz był w niej obecny tylko ze względu na dekorację zasłużonych.

Duży udział E. Gierka można zanotować w kronice z 1978 r. związanej z lotem w kosmos M. Hermaszewskiego. Przez znaczną część materiału przybliżano widzom historię i nowinki dotyczące lotów kosmicznych, natomiast I sekretarz pojawił się w czasie odbierania meldunku od kosmonautów, którym złożył gratulacje, w ławach sejmowych wysłuchując przemówienia M. Hermaszewskiego, a następnie w trakcie własnej mowy sejmowej. Wedle niej, ów lot podkreślał braterstwo między Polską i ZSRR ${ }^{144}$. Udział przywódcy partii w takim wydarzeniu wynikał z pełnionej funkcji, ale mógł być wykorzystany dla wzmocnienia jego pozytywnego wizerunku. Zainteresowanie techniką radziecką, prezentowane także we wcześniejszych kronikach mogło świadczyć, że lot w kosmos był po części sukcesem I sekretarza.

Gierek pojawiał się w materiale z 1975 r. poświęconym XXX-leciu „Chłopskiej drogi”. Był ukazany w trakcie podziękowań skierowanych wobec gazety $^{145}$, co mogło świadczyć o ważnej roli, jaką pełniła w partii kwestia chłopska.

141 Ibidem.

142 http://kronikarp.pl/szukaj,31984,strona-3, dostęp: 23.04.2017, Lista montażowa PKF 46B/75.

143 http://kronikarp.pl/szukaj,42207,strona-3, dostęp: 23.04.2017.

144 https://www.youtube.com/watch?v=pWz-yIhDRkU, dostęp: 23.04.2017; Lista montażowa PKF 35A/78.

145 http://kronikarp.pl/szukaj,31986,strona-3, dostęp: 23.04.2017; Lista montażowa PKF $46 \mathrm{~B} / 75$. 
W 1974 r. I sekretarz został przedstawiony w materiale Spotkanie młodych ${ }^{146}$. W czasie przemów szczególnie zaznaczono rolę młodzieży. Po wystąpieniach delegatów podchodzący do mównicy I sekretarz został przyjęty gromkimi brawami. Następnie pojawiły się ujęcia na zgromadzonych i przywódcę partyjnego podczas mowy. Podkreśleniem znaczenia ludzi młodych była dekoracja zasłużonych Orderem Sztandaru Pracy.

W 1976 r. miał miejsce Kongres Młodzieży Polskiej, z którego relacja pojawiła się w PKF w materiale o wymownym tytule Silni jednościq ${ }^{147}$. Był on związany z konsolidacją dotychczasowych organizacji młodzieżowych. Gierek został przedstawiony podczas przybycia na miejsce wśród oklasków zgromadzonych młodych ludzi. Przedstawiciele złożyli mu meldunek, po czym nastąpiła pełna przemowa I sekretarza, w której silnie akcentowano rolę zgromadzonych. W późniejszej części materiału skupiono się na młodzieży. W maju 1980 r. pojawiła się relacja z II Krajowego Zjazdu ZSMP. Po ujęciach na uczestników ukazano E. Gierka, poruszającego się wśród ludzi młodych, po czym miała miejsce jego długa przemowa przerywana ujęciami na salę ${ }^{148}$. Na zakończenie głos zabrali delegaci. Podkreślenie udziału I sekretarza w wydarzeniach związanych z młodzieżą pojawiało się wielokrotnie w kronice. Świadczyć mogło o zainteresowaniu władz jej losem, ponieważ miała stanowić przyszłość ojczyzny. Nagrania te, wraz z innymi kronikami, dotyczącymi ludzi młodych, podkreślały ich znaczenie w społeczeństwie oraz wskazywały, że to właśnie na nich opiera się przyszłość narodu.

Ciekawym materiałem była relacja ze spotkania E. Gierka z czterema polskimi specjalistami, którzy zostali uprowadzeni w Iraku. I sekretarza ukazano w czasie przywitania z przybyłymi, krótkiej przemowy i wspólnej dyskusji. Lektor podkreślił rodzinną atmosferę spotkania, wzruszenie, a co ważniejsze duże wysiłki władz mające na celu uratowanie porwanych.

Poruszyliśmy wszystkie sprężyny międzynarodowe: ONZ, rząd Iraku, rządy kilku zaprzyjaźnionych krajów. Dotarliśmy do wielu organizacji kurdyjskich.

Starania zostały uwieńczone sukcesem ${ }^{149}$.

Przekaz kroniki zdawał się wskazywać, że władze PRL-u starały się dbać o swoich obywateli, także tych, którzy znajdowali się poza granicami kraju. Mógł także podkreślać opiekuńczą rolę partyjnego przywódcy. Jednocześnie wskazano na znaczenie polityki zagranicznej prowadzonej przez niego w ostatnich latach, która miała przynosić nawet tak niespodziewane efekty.

\footnotetext{
146 Lista montażowa PKF /74.

147 Lista montażowa PKF 19B/76.

148 Lista montażowa PKF 18B/80.

149 http://kronikarp.pl/pop-up.php?id=34212\&type=2, dostęp: 22.05.2017.
} 
W PKF próbowano przedstawić E. Gierka jako osobę bliską całemu społeczeństwu, zaangażowaną w jego rozwój, a także słuchającą głosu obywateli. Szczególnie podkreślano to w I poł. lat siedemdziesiątych, co mogło się wiązać z próbą legitymizacji społecznej. Stopniowo widać jednak pewne zmniejszenie tendencji do pokazywania I sekretarza jako orędownika liberalnych zmian, co mogło się wiązać z odnoszonymi sukcesami, a także pozytywną sytuacją ekonomiczną i społeczną kraju. Pod koniec lat siedemdziesiątych dostrzegalne są próby odbudowy tego wizerunku, jednak okazały się one bezskuteczne. Istotnym szczegółem wydaje się częsty udział premiera P. Jaroszewicza przy boku E. Gierka, co mogło być wiązane z hasłem epoki partia kieruje, rząd rzq̨dzi ${ }^{150}$.

\section{Gospodarskie wizyty}

Gierek w przeciwieństwie do swojego poprzednika doceniał rolę mediów audiowizualnych i to właśnie za ich pomocą starał się przekonać społeczeństwo do swoich pomysłów ${ }^{151}$. Tym samym musiał dobrze się prezentować, czy też sprawiać takie wrażenie w mediach, zwłaszcza na ekranie, gdzie wygląd i zachowanie ma niebagatelne znaczenie. Zmieniły się także pewne metody działalności przywódców politycznych. Przechodził on „z ulicy” do studia radiowego i telewizyjnego ${ }^{152}$. Nadal jednak starał się bezpośrednio wpływać na odbiorców, jednak dzięki mediom audiowizualnym zwiększyła się grupa bezpośrednich odbiorców. Taką właśnie funkcję miały „gospodarskie wizyty". Pod tą nazwą kryją się spotkania E. Gierka z pracownikami różnych zakładów pracy, żołnierzami, bądź rolnikami. W przyjętej przeze mnie klasyfikacji musiały odbywać się one na terenie danego przedsiębiorstwa, placu budowy czy też jednostki wojskowej, ponieważ była to wizyta dygnitarzy partyjnych, nie zaś delegatów zakładowych. Włączyłem w to grono także mające miejsce w okresie letnim spotkania z młodzieżą podczas różnych obozów i czynów społecznych oraz obecność podczas inauguracji nowego roku akademickiego. Warto również podkreślić, że tylko w trzech przypadkach materiał z E. Gierkiem był wyświetlany jako drugi w kolejności. Za każdym razem poprzedzały je relacje z wizyt zagranicznych różnych dygnitarzy partyjnych (bez udziału I sekretarza). Świadczy to o priorytetowym znaczeniu nagrań związanych z E. Gierkiem.

150 E. Gierek, op. cit., s. 93.

151 K. Pokorna-Ignatowicz, Telewizja w systemie politycznym i medialnym PRL. Między politykq a widzem, Kraków 2003, s. 107-110.

152 J. Mazurek, Z teorii propagandy socjalistycznej, Warszawa 1974, s. 138. 
Do 1976 r. wyłoniłem w sumie 46 materiałów z PKF, które można zakwalifikować do „gospodarskich wizyt”, zaś w latach następnych już tylko 10, w tym dwa znajdujące się całkowicie w „odrzutach”. Szczegółowe informacje na temat poszczególnych lat znajdują się w poniższej tabeli:

\begin{tabular}{|c|c|c|c|c|c|c|c|c|c|c|c|}
\hline Rok & 1970 & 1971 & 1972 & 1973 & 1974 & 1975 & 1976 & 1977 & 1978 & 1979 & 1980 \\
\hline $\begin{array}{c}\text { Gosp. } \\
\text { wizyty }\end{array}$ & 0 & 11 & 9 & 7 & 9 & 4 & 6 & 5 & $1(1)$ & 1 & $1(1)$ \\
\hline
\end{tabular}

Tabela przedstawia „gospodarskie wizyty” w PKF na podstawie kwerendy w Filmotece Narodowej Instytucie Audiowizualnym. Liczby w nawiasach przedstawiają materiały znajdujące się wyłącznie w „odrzutach”.

Spośród materiałów filmowych zawierających "gospodarskie wizyty" można wyróżnić kilka ich typów:

- spotkania w zakładach pracy,

- na wielkich budowach państwowych,

- z młodzieżą,

- podczas uroczystości takich jak barbórka czy inauguracja nowego roku akademickiego,

- wydarzeniach cyklicznych jak np. Międzynarodowe Targi Poznańskie ${ }^{153}$.

Ze względu na funkcję informacyjno - poznawczą propaganda powinna wpływać na postawy, myślenie i działanie odbiorcó $w^{154}$. Dlatego też kluczową rolę w kreowaniu wizerunku politycznego odgrywały w PKF „gospodarskie wizyty". Przed kierownictwem kroniki postawiono zadanie tworzenia odpowiedniego klimatu dla propagandy sukcesu, jednak cele i strategie działań były oparte na zaleceniach i dyrektywach opracowywanych przez biurokrację partyjną. Ów model PKF jedynie realizowała, z większym lub mniejszym skutkiem. Miała ona stać się narzędziem partii, przez co musiała być dyspozycyjna ${ }^{155}$.

Tournée polityczne po prowincji to jeden z bardziej znanych chwytów wyborczych. W PRL-u wykorzystano go w celu wzmocnienia wizerunku

${ }^{153} \mathrm{~W}$ tych materiałach E. Gierek pojawia się jedynie podczas zwiedzania pawilonów wystawowych.

154 J. Mazurek, op. cit., s. 138-139.

155 Mirosław Chrzanowski, redaktor naczelny PKF w latach 1973-81 potwierdza, że kronika znajdowała się pod pełnym nadzorem KC PZPR, http://www.kronikarzprl.com.pl/spis-tre\%C5\%9Bci/16-\%C5\%9Bwiat-socjalizmu/, dostęp: 9.07.2017. 
E. Gierka. Siłą takiego wyjazdu był kontakt ze „zwykłymi ludźmi”. Uściśnięcie dłoni, szczególnie podkreślane w materiałach z terenu, wiąże silnie daną osobę z politykiem, ale także wzbudza zaufanie. W czasie takiej wizyty sprawiało się wrażenie wejścia w rolę społeczną odwiedzanych. Celem wyjazdu było przekazanie obrazu propagandowego jak największej liczbie potencjalnych wyborców ${ }^{156}$. W przypadku państw demokracji ludowej, gdzie wybory nie odgrywały swej pierwszorzędnej roli wizyty miały pokazać więź władzy z obywatelami, świadomość potrzeb społeczeństwa i znajomość warunków pracy. Były również dobrą okazją do zaprezentowania szerokiego poparcia społecznego wobec I sekretarza, zwłaszcza wśród klasy robotniczej. W pierwszych materiałach filmowych po przejęciu władzy w partii przez E. Gierka podkreślano przekazywanie przez niego informacji robotnikom na temat planów rozwoju państwa, pojawiła się krytyka poprzednich, błędnych rozwiązań - w domyśle związanych z poprzednią, skompromitowaną ekipą. Przejawiało się to w słowach lektora: Krytykowano i radzono. Wyrażano sprzeciw wobec dotychczasowych niedobrych praktyk ${ }^{157}$. Szczególnie podkreślano wagę rozmowy z pracownikami, którzy następnie wyrażali zrozumienie i zapewniali o solidnej pracy. Zaznaczano także rolę „dobrej roboty”, prowadzącej do rozbudowy kraju.

Podczas przeglądania list montażowych dotyczących odwiedzin zakładów przemysłowych przez E. Gierka można dostrzec zarys schematyczności. Jako pierwszy na ekranie widniał tytuł materiału filmowego, po czym przedstawiano widok ogólny miejscowości, przedsiębiorstwa czy też placu budowy ${ }^{158}$. Następnie pojawiały się kadry z załogą podczas pracy. Były to zarówno plany ogólne, jak i zbliżenia na poszczególne osoby, często przedstawiano maszyny w ruchu ${ }^{159}$. W kolejnych ujęciach pojawiał się E. Gierek, który w otoczeniu przedstawicieli zakładu był wprowadzany na jego teren. Wysłuchiwał on wówczas uwag pracowników, bądź też raczej warstwy kierowniczej, na co mógł wskazywać ich ubiór. W kolejnych fragmentach materiałów nie było już tak ściśle określonego schematu, co było spowodowane specyfiką poszczególnych zakładów/terenów budów, niemniej jednak ważną rolę w nich odgrywał dynamizm. E. Gierka w większości przypadków ukazywano w ruchu i pośród ludzi, którzy otaczali go z kilku stron. Pojawiało

156 W. Jabłoński, Kreowanie informacji. Media relations, Warszawa 2006, s. 152.

157 Lista montażowa PKF 4B/71, http://kronikarp.pl/pop-up.php?id=11392\&type=2, dostęp: 22.05.2017.

158 Lista montażowa PKF 3A/71, 29A/73, 7A/75, http://kronikarp.pl/szukaj,12266, strona-2, dostęp: 9.07.2017; http://kronikarp.pl/szukaj,33212,strona-2, dostęp: 9.07.2017; http://kronikarp.pl/szukaj,53715,strona-3, dostęp: 9.07.2017.

159 Lista montażowa PKF 51A/73, http://kronikarp.pl/szukaj,55833,strona-2, dostęp: 9.07.2017. 
się wiele ujęć na zgromadzone tłumy. Gdy środki techniczne na to pozwalają operator starał się pokazać je z wysokości, co uwydatniało liczną obecność załogi. Zawsze towarzyszyli mu inni wysocy rangą działacze partyjni.

W przypadku wizyty w zakładach pracy bądź na budowach pojawiały się migawki z wizytacji stanowisk produkcyjnych i doglądania warunków pracy. E. Gierek sprawiał wtedy wrażenie zainteresowanego sytuacją robotników, kondycją zakładu a także realizacją planów ekonomicznych. Elementem, który pojawił się w późniejszym czasie było dekorowanie pracowników Orderami Sztandaru Pracy. Media rzadko są przypadkowym świadkiem wydarzeń, najczęściej są przyciągnięte przez PR-owców by relacjonować przygotowane wcześniej sytuacje ${ }^{160}$. W przypadku PKF, gdzie przekaz medialny podporządkowany jest kierownictwu partii wszystkie takie wizyty były świadomą kreacją rzeczywistości.

W analizowanych przeze mnie materiałach pochodzących z PKF najczęściej pojawiał się tuż obok E. Gierka premier P. Jaroszewicz. Być może miało to związek z jego silną pozycją w kręgach rządzących, a także z faktem, że gospodarka krajowa miała mieć dla I sekretarza priorytetowe znaczenie. Drugą wiele razy obecną w pobliżu towarzysza Edwarda osobą był Przewodniczący Rady Państwa H. Jabłoński, co zapewne miało związek z charakterem tej instytucji. W znaczeniu propagandowym przedstawiało to jedność najwyższych czynników partyjnych i państwowych oraz ich współdziałanie ku lepszej przyszłości narodu. Przejawiało się to właśnie w gospodarskich wizytach, podczas których mogli oni (przynajmniej teoretycznie) wysłuchać problemów klasy robotniczej, a także sugestii związanych z funkcjonowaniem zakładu bądź przedsiębiorstwa, a nawet dotyczących państwa. W rzeczywistości jednak były one przedstawiane w sposób laurkowy ${ }^{161}$, a przytoczone problemy miały charakter branżowy i po wykonaniu odpowiedniej pracy zostaną przezwyciężone. Wyjątek w tym stanowi PKF z początku 1971 r., w której wyemitowano materiał pt. Obywatelska rozmowa ${ }^{162}$. Owa dyskusja miała miejsce w stoczniach Szczecina oraz Gdańska i była bezpośrednio związana z wydarzeniami na Wybrzeżu. Podczas materiału filmowego spiker wyraźnie podkreślał, że władze partyjne wysłuchały wszystkich uwag stoczniowców związanych zarówno z sytuacją ekonomiczną, jak i Grudniem '70, mimo niejednokrotnie gorzkich słów. Na koniec materiału podkreślono jednak, że robotnicy zgadzają się z obecnymi koncepcjami władz partyjnych.

160 W. Jabłoński, op. cit., s. 30.

161 J. Rolicki, op. cit., s. 147.

162 Lista montażowa PKF 4B/71. http://kronikarp.pl/szukaj,11392,strona-2, dostęp: 24.05. 2017, https://www.youtube.com/watch?v=uIoKP6dOlC4, dostęp: 24.05.2017. 
Wybrzmiało również postanowienie: Pomożemy dźwigać Polskę. Jesteśmy za niq współodpowiedzialni ${ }^{163}$.

Kolejną z osób, które często pojawiały się przy E. Gierku był generał W. Jaruzelski, ówczesny Minister Obrony Narodowej ${ }^{164}$. Brał udział w wizytacji jednostek wojskowych w koszarach ${ }^{165}$, bądź podczas spełniania zobowiązań podjętych przez wojsko, czy podczas manewrów ${ }^{166}$. Pojawił się także w czasie rozmów ze stoczniowcami w Szczecinie ${ }^{167}$. Zawsze zaznaczano rozmowę I sekretarza z żołnierzami, co być może miało przedstawić jego zainteresowanie nawet najmniejszymi trybikami w wojskowej machinie. Najlepszym tego przykładem była budowa i oddanie do użytku estakady w Częstochowie w 1976 r., gdzie oddał nożyce do przecięcia wstęgi jednemu z żołnierzy ${ }^{168}$. Był to miły ukłon, który mógł podkreślać rolę budujących, a I sekretarza przedstawić jako osobę nie zwracającą uwagi na zaszczyty.

W czasie wizyt międzynarodowych delegacje zagraniczne podczas programu zwiedzały różnego rodzaju zakłady pracy. W tym czasie towarzyszyły im czynniki partyjne różnego szczebla, w zależności od rangi wizyty, jednak nie brał w nich udziału E. Gierek. Wyjątek stanowiły delegacje Związku Radzieckiego, czego przykładem były materiały Historia budowy huty Katowice $^{169}$, kronika przypominająca wizytę sekretarza generalnego na Śląsku ${ }^{170}$, czy też XXX-lecie huty im. Lenina. W tych fragmentach delegacja z L. Breżniewem nie tylko wizytowała zakład, lecz nawet sam plac budowy. Sam I sekretarz KC KPZR prowadził dyskusję z robotnikami i otrzymał Odznakę hutnika. Oprowadzanie przez E. Gierka delegacji z Moskwy pokazuje jej znaczenie dla władz PRL-u.

Dynamizm w materiałach filmowych mógł zostać dodatkowo podkreślony poprzez pokazanie samego momentu przybycia I sekretarza do miejsca docelowego. Przywódcę partii można było wtedy najczęściej zobaczyć w trakcie rozmowy z ważnymi przedstawicielami danej społeczności lub prominentnymi działaczami partyjnymi z danego regionu ${ }^{171}$. Odnosiło się wrażenie, że starali się oni przybliżyć mu problemy swoich okolic. Podczas przywitania

163 Ibidem.

164 L. Kowalski, op. cit., s. 424.

165 Lista montażowa PKF 27A/79.

166 Lista montażowa PKF 39A/76.

167 Lista montażowa PKF 4B/71. http://kronikarp.pl/szukaj,11392,strona-2, dostęp: 24.05. 2017; https://www.youtube.com/watch?v=uIoKP6dOlC4, dostęp: 24.05.2017.

${ }^{168}$ Lista montażowa PKF 42B/76.

169 Lista montażowa PKF 52B/76.

170 http://kronikarp.pl/szukaj,42757,strona-2, dostęp: 9.07.2017.

${ }^{171}$ Lista montażowa PKF 3A/71, 4B/71, 51A/73, 7A/75, http://kronikarp.pl/szukaj,55833, strona-2, dostęp: 9.07.2017 r.; http://kronikarp.pl/szukaj,53715,strona-3, dostęp: 9.07.2017. 
pojawiali się najczęściej młodzi ludzie, wręczający kwiaty towarzyszowi sekretarzowi. Sprawiał on wówczas wrażenie naturalności poprzez swobodne dyskusje z pracownikami. Jest to świadoma gra na emocjach widza, który miał dostrzec w E. Gierku naturalnego i bezpośredniego człowieka. Zacierała się wówczas różnica między rzeczywistością medialną a realnym światem w związku z pełnieniem prze nie funkcji propagandowych ${ }^{172}$.

W każdym materiale w którym była mowa o wizytach przywódcy PZPR w zakładach pracy lub danym mieście pokazywano bliskie ujęcia na zgromadzoną publiczność. Przedstawiały one w większości słuchających w skupieniu widzów, lub rozmawiających z I sekretarzem przodowników pracy.

W PKF „gospodarskie wizyty" były najczęściej w całości relacjonowane przez lektora, sporadycznie zaś pojawiały się w nich fragmenty przemówienia E. Gierka, czy też rozmowy z pracownikami ${ }^{173}$. Zdecydowany głos spikera dynamizował materiał filmowy, a także kondensował zawartość kroniki, co miało niebagatelne znaczenie dla jej atrakcyjności.

Obowiązkowym elementem pojawiającym się w PKF były relacje z Dnia Górnika, czyli Barbórek. Udział w nich E. Gierka nie powinien dziwić ze względu na jego życiorys, który podkreślano w materiałach ${ }^{174}$. W $1971 \mathrm{r}$. w związku z tym świętem odwiedził górników w kopalni „Borynia”, wśród których uruchomił nowoczesną maszynę wyciągową ${ }^{175}$. Świadczyć to miało zapewne o znajomości tego zawodu, co silnie wiązało go z załogą. Nie zabrakło także dekoracji przodowników pracy i sztandarów, a te elementy zagościły na stałe w kolejnych relacjach z Barbórek. W kolejnych latach przywódcę partii filmowano nie tylko w trakcie wizytacji kopalni, ale także podczas uroczystych akademii w wypełnionych po brzegi górnikami salach ${ }^{176}$. Ponadto towarzysz sekretarz pojawił się podczas odwiedzin w szpitalu górniczym ${ }^{177}$.

Barwniejszy przebieg miały spotkania z młodzieżą, które również możemy zaliczyć do gospodarskich wizyt. Były to różnego rodzaju zloty młodych przodowników pracy bądź wizytacje podczas realizacji zobowiązań. Zwykle miały one miejsce $\mathrm{w}$ lecie, podczas przerwy od nauki szkolnej. Schemat wizyt był podobny do tych w zakładach pracy, jednak materiały z młodzieżą pojawiały się do 1980 r. pomimo spadku popularności władz partyjnych. Podczas tych materiałów E. Gierek był pokazywany przede wszystkim w otoczeniu młodzieży, która podczas jego przyjazdu sprawiała

\footnotetext{
${ }^{172}$ W. Jabłoński, op. cit., s. 32-33.

173 https://www.youtube.com/watch?v=XVNggkLXP-Q\&list=PL24874077667666B2, dostęp: 15.09.2018.

174 Lista montażowa PKF 49B/74.

175 Lista montażowa PKF 49A/71.

176 Lista montażowa PKF 49A/72.

177 Lista montażowa PKF 50B/77.
} 
przywódcy gorącą owację ${ }^{178}$. W jednym z materiałów był on wprowadzany przez dwie dziewczyny trzymające go pod ręce ${ }^{179}$. Rozmowy z towarzyszem sekretarzem miały miły i pozytywny charakter, o czym świadczyły uśmiechy młodzieży na każdym kroku. Przykładem był materiał Frombork 1001 PKF z 1971 r., w którym E. Gierek otrzymał krzyż Za zasługi dla ZHP, a spiker podkreślił jego zaangażowanie w sprawy młodzieży:

Wielokrotnie mówił Edward Gierek z serdeczną przyjaźnią o roli młodzieży w dziele dobrej roboty. Frombork jest jej praktycznym i pięknym przykładem ${ }^{180}$.

Z kolei w roku następnym pojawił się wśród ludzi młodych z chustą harcerską, co mogło świadczyć o jego bliskiej relacji z odwiedzanymi, a także zaufaniu, jakim go darzyli ${ }^{181}$.

Materiałami pośrednio związanymi z młodzieżą były relacje z inauguracji roku akademickiego, jakie kilkukrotnie pojawiały się w kronice. Mógł to być także ukłon w stronę inteligencji. Gierka przedstawiano jako uczestnika uroczystości ${ }^{182}$, rzadziej $\mathrm{w}$ trakcie oficjalnej przemowy ${ }^{183}$ bądź dekoracji sztandarów ${ }^{184}$. Jedynie $\mathrm{w}$ relacji z 1974 r. pojawiło się wręczenie mu insygniów Politechniki Śląskiej, w podziękowaniu za wieloletniq partyjna inspirację $e^{185}$.

Ciekawym podsumowaniem „gospodarskich wizyt” był materiał z okazji sześćdziesiątych urodzin I sekretarza, które miały miejsce w 6 stycznia 1973r. Oprócz wizyty niewielkiej delegacji pracowniczej, co mogło świadczyć o jego skromności, znalazły się tam skróty z kilku wyjazdów I sekretarza do różnych zakładów pracy. Można zatem zobaczyć E. Gierka zwiedzającego kopalnię, podczas uroczystości barbórkowych, wizytacji budów czy też innych zakładów przemysłowych. Znamienny wydaje się tekst lektorski:

liczne spotkania Edwarda Gierka z załogami stały się dobrym zwyczajem. Wszędzie jest witany jako ktoś najbliższy. I sekretarz KC odnosi się z szacunkiem i zaufaniem do opinii publicznej. Społeczeństwo odwzajemnia się tym samym $^{186}$.

178 Lista montażowa PKF 30A/72, 34A/72.

179 Lista montażowa PKF 30A/71.

180 http://kronikarp.pl/szukaj,13542,strona-2, dostęp: 22.05.2017.

181 Lista montażowa PKF 30A/72.

182 Lista montażowa PKF 40A/72.

183 Lista montażowa PKF 41A/76.

184 Lista montażowa PKF 41A/77.

185 Lista montażowa PKF 40B/74, https://www.youtube.com/watch?v=KqU7T1qHOeQ\&t =70s, dostęp: 14.03.2019.

186 Lista montażowa PKF 2A/73, http://kronikarp.pl/szukaj,32488,strona-2, dostęp: 20.05. 2017. 
Miał on w sobie duży ładunek propagandowy. Z jednej strony pokazywał I sekretarza jako reformatora, który starał się naprawić błędy swojego poprzednika, a tym samym stosował zupełnie odmienną politykę wobec społeczeństwa. Jednocześnie chwalono "gospodarskie wizyty”, traktowane jako swego rodzaju odwiedziny. Słowa dotyczące bliskości I sekretarza, wzmocnione poprzez przedstawienie całującej E. Gierka kobiety w chustce ${ }^{187}$, podkreślały zaistniałe zmiany w relacjach władza - społeczeństwo. Celem tych działań mogła być zarówno próba wpłynięcia na robotników by zwiększyli swoją wydajność, jak i ukazanie go jako demokraty, który potrafi w systemie komunistycznym zdobyć realne zaufanie i odnosić sukcesy.

Ogólne zarysy „gospodarskich wizyt” nie zmieniały się w ciągu całej „dekady Gierka" i stanowiły próbę zbliżenia kierownictwa partii ze społeczeństwem, lub raczej miały jedynie sprawiać takie wrażenie. Stosowano podczas nich podstawowe zasady prowadzenia kampanii wyborczej, jak również najważniejsze elementy propagandy komunistycznej. W początku lat siedemdziesiątych spełniały swoje założenia ${ }^{188}$, jednak z powodu nadmiernego ich używania stały się nudne i mało atrakcyjne. Dodatkowo z racji wcześniejszego informowania o planowanym przyjeździe I sekretarza przynosiły one nikłe korzyści i wyglądały nienaturalnie ${ }^{189}$.

\section{Podsumowanie}

Po analizie dostępnych materiałów filmowych Polskiej Kroniki Filmowej, wszystkich list montażowych PKF, w których pojawiała się postać E. Gierka, a także literatury przedmiotu, wydaje się być zasadną teza, że wizerunek I sekretarza KC PZPR przedstawiany w kronice był pewną kreacją.

Jego "krajowy” charakter wiązał się przede wszystkim z początkami sprawowania władzy przez E. Gierka i wydaje się, że miała na nią wpływ napięta sytuacja społeczna w państwie. Z racji cech jakie posiadał, a które w sposób znaczący różniły go od swojego poprzednika mógł (podejmując pewne ryzyko) przy pomocy różnych mediów kreować się na osobę otwartą na problemy społeczeństwa, zainteresowaną sytuacją materialną obywateli, a także próbującą rozwiązać zaistniałe patologie. Szczególnie ważne były materiały ze stycznia 1971 r., w których relacjonowano jego wizyty w głównych ogniskach protestów. Podkreślenie odniesionego sukcesu i otwartości pomogło zażegnać konflikty, a także stało się zalążkiem późniejszych „gospodarskich wizyt". Tego typu materiały różniły się w swoim schemacie. Początkowo

\footnotetext{
187 Ibidem.

188 J. Tejchma, op. cit., s. 38.

189 M. Rakowski, op. cit., s. 160; J. Rolicki: Edward Gierek. Replika, Warszawa 1990, s. 147-148.
} 
wspólnie z kronikami promującymi I sekretarza w większym stopniu miały przedstawić jego sylwetkę ogółowi społeczeństwa, później zaś stanowiły próbę ukazania go jako dobrego gospodarza, którego działania przyczyniły się do dynamicznego rozwoju kraju. Wzmacniało to wrażenie opieki E. Gierka nad obywatelami, a także zainteresowania ich problemami. Sprawiało także wrażenie, że I sekretarz sam wciela się w rolę administratora i dba o dobro państwa i społeczeństwa. Ciekawą próbą „zbliżenia” władzy do obywateli była zmiana formuły przedstawiania pochodów pierwszomajowych. Przejście dygnitarzy partyjnych w pierwszym szeregu wzmacniało ich więź z maszerującymi, jednak kluczową rolę pełniła zmiana optyki marszu, która sprawiała wrażenie łączności uczestniczących w pochodzie z obecnymi na trybunie, a tym samym zmniejszenia dystansu na linii władza - społeczeństwo.

W materiałach z wizyt w zakładach pracy podkreślano znaczenie „dobrej roboty", które to hasło miało zaktywizować społeczeństwo we wspólnych wysiłkach $\mathrm{w}$ celu zwiększenia produktywności i wydajności pracy. $\mathrm{W}$ tym kontekście pojawiały się częste nagrania związane z ulubionym regionem I sekretarza, którym był Śląsk. Wiązało się to z jego pochodzeniem, pracą zawodową, a także poprzednimi stanowiskami partyjnymi. Tym samym często akcentowano górniczy element jego życiorysu, co w przypadku partii opartej na władzy mas pracujących miało niebagatelne znaczenie. Jednak całość takiego przekazu medialnego, prawdopodobnie na skutek pogarszającej się sytuacji gospodarczej odniosła fiasko. W związku z tym praktycznie zaprzestano przedstawiania tego typu materiałów po 1977 r., ponieważ nie można było skutecznie kreować wizerunku partyjnego przywódcy w oderwaniu od rzeczywistości.

Częste podkreślanie roli ludzi młodych, wśród których chętnie pojawiał się E. Gierek, a stanowiących znaczny procent ówczesnego społeczeństwa, miało prawdopodobnie przekonywać o otwarciu na problemy przyszłości, bez czego nie można myśleć o rozwoju kraju. Pojawianie się I sekretarza w kręgu młodzieży mogło także odmładzać oraz zatrzeć wrażenie wyobcowania młodego pokolenia powiązane z brakiem zrozumienia przez starszych. Jednocześnie było wyjściem naprzeciw oczekiwaniom społeczeństwa, ponieważ w latach siedemdziesiątych na rynek pracy wchodziła nowa fala wyżu demograficznego. Podkreślanie znaczenia młodzieży mogło być próbą zaskarbienia sobie ich przychylności, oraz wciągnięcia ludzi młodych do PZPR lub innych organizacji powiązanych z władzą komunistyczną.

Podczas oglądania materiałów kroniki, a także w czasie przeglądania list montażowych można dojść do wniosku, że starano się uwypuklić pozytywne cechy E. Gierka, a także jego potencjalne atuty. Szczególnie istotne wydaje 
się być podkreślanie bezpośredniości I sekretarza, jego relacji z obywatelami, a pośrednio odmiennego od poprzednika stylu pracy. Wzmocniony tymi akcentami wizerunek E. Gierka w PKF niewątpliwie musiał sprawiać korzystne wrażenie, a tym samym zwiększać grono osób pozytywnie go oceniających. Spełniał zatem swoje propagandowe zadanie.

W przypadku materiałów związanych z PZPR i rządem, można dostrzec próbę budowania wizerunku I sekretarza jako pasma sukcesów. Przejawiały się one przy jednomyślności aktywu i społeczeństwa, którego rolę próbowano wzmacniać poprzez podkreślanie obecności osób bezpartyjnych (co mogło być kolejną próbą aktywizacji). Szczególne zaznaczanie roli wyborów miało wskazywać na poparcie obywateli. W czasie najlepszej koniunktury widać było zaniechanie tego typu narracji, która znów powróciła w latach kryzysu. Materiały kroniki ukazują E. Gierka jako kogoś w rodzaju „ojca narodu". Można odnieść wrażenie pewnego rozejścia się właściwej funkcji I sekretarza KC PZPR z tym, co było pokazywane w PKF. Mogło się to wiązać $\mathrm{z}$ próbą budowy podwalin pod urząd prezydenta PRL-u.

Radykalny krach związany z próbą budowy "krajowego” wizerunku E. Gierka nastąpił w 1979 r. i było to związane z nieprzygotowaniem do odparcia silnego ataku zimy, który w ostateczności pogrążył gospodarkę PRL-u, a wraz z nią I sekretarza.

Nie zmieniło to jednak faktu, że PKF zwłaszcza w pierwszej połowie lat siedemdziesiątych silnie zaangażowała się $\mathrm{w}$ kampanię propagandową mającą na celu wzmocnienie wizerunku E. Gierka, a także stworzenie atmosfery budującej silne zaufanie społeczeństwa wobec I sekretarza. Było to niezwykle istotne w kontekście Grudnia'70 i ogólnego kryzysu stosunków na linii władza - obywatele. Do jego zażegnania mogła przyczynić się i kronika.

Podsumowując, obraz E. Gierka w PKF był świadomą próbą kreacji I sekretarza KC PZPR w postaci męża stanu. Ukazywano go jako oddanego obywatelom dobrego gospodarza, który prowadzi swój kraj do rozwoju ekonomicznego. Spójność tego wizerunku w przekazie kroniki zakończyła się w 1977 r. najprawdopodobniej na skutek trudności wewnętrznych państwa. W początkach lat osiemdziesiątych PKF nie oddziaływała, aż tak bardzo silnie propagandowa, jako miało to miejsce w „epoce Gierka”. 


\section{BIBLIOGRAFIA}

\section{Źródła audiowizualne}

Listy montażowe PKF z 1970 r.: 51A/70, 52AB/70.

Listy montażowe PKF z 1971 r.: 3A/71, 4B/71, 6A/71, 7A/71, 15A/71, 18A/71, 19A/71, $30 \mathrm{~A} / 71,36 \mathrm{~A} / 71,36 \mathrm{~B} / 71,48 \mathrm{~B} / 72,49 \mathrm{~B}-50 \mathrm{~A} / 71,51 \mathrm{~B} / 71$.

Listy montażowe PKF z 1972 r.: 5A/72, 8B/72, 12A/72, 13B/72, 14B/72, 30A/72, 34A/72, $36 \mathrm{~A} / 72,40 \mathrm{~A} / 72,48 \mathrm{~A} / 72$.

Listy montażowe PKF z 1973 r. 2A/73, 18A/73, 26A/73, 29A/73, 36A/73, 36B/73, 39A/73, 41 $\mathrm{B} / 73,42 \mathrm{~A} / 73,43 \mathrm{~A} / 73,45 \mathrm{~A} / 73,46 \mathrm{~A} / 73,51 \mathrm{~A} / 73$.

Listy montażowe PKF z 1974 r.: 6B/74, 8B/74, 20A/74, 28B/74, 29AB/74, 33AB/74, 37B/74, $42 \mathrm{~A} / 74,49 \mathrm{~B} / 74$.

Listy montażowe PKF z 1975 r.: 2B/75, 5B/75, 7A/75, 15A/75, 17A/75, 18B/75, 20A/75, $22 \mathrm{~B} / 75,37 \mathrm{~A} / 75,46 \mathrm{~B} / 75$.

Listy montażowe PKF z 1976 r.: 4B/76, 13A/76, 14A/76, 19B/76, 28B/76, 38B/76, 39A/76, 42B/76, 52B/76.

Listy montażowe PKF z 1977 r:: 18A/77, 31A/77, 39A/77, 50B/71.

Listy montażowe PKF z 1978 r.: 2B/78, 37A/78.

Listy montażowe PKF z 1979 r.: 20A/79, 27A/79, 36B/79, 37A/79.

Listy montażowe PKF z 1980 r.: 7B/80, 8A/80, 11A/80, 13A/80, 15A/80, $18 \mathrm{~B} / 80$.

\section{Źródła drukowane}

Rakowski M., Dzienniki polityczne 1969-1971, Warszawa 2001.

Rakowski M., Dzienniki polityczne 1972-1975, Warszawa 2002.

Rakowski M., Dzienniki polityczne 1976-1978, Warszawa 2002.

Rakowski M., Dzienniki polityczne 1979-1981, Warszawa 2004.

Tejchma J., Kulisy dymisji: Z dzienników ministra kultury 1974-1977, Kraków 1991.

Tejchma J., Odszedł Gomułka, przyszedł Gierek: Notatki z lat 1971-1973, Toruń 2006.

\section{Pamiętniki}

Gierek E., Smak życia: Pamiętniki, Warszawa 1993.

\section{Źródła internetowe}

http://www.gazetakrakowska.pl/artykul/732281,chcesz-cukierka-idz-do-gierka,id,t.html, dostęp: 14.05.2017.

http://www.kronikarzprl.com.pl/spis-tre\%C5\%9Bci/9-cenzura/, dostęp: 9.07.2017.

http://www.kronikarzprl.com.pl/spis-tre\%C5\%9Bci/16-\%C5\%9Bwiat-socjalizmu/, dostęp:

9.07.2017. 
https://www.youtube.com/watch?v=1DEpSzygcMU\&list=PL9FF6C55341DB4BF6, dostęp: 23.04.2017.

https://www.youtube.com/watch?v=2X4stbnNWDA\&t=68s, dostęp: 22.05.2017.

https://www.youtube.com/watch?v=BBOQq-uClJM, dostęp: 23.04.2017.

https://www.youtube.com/watch?v=hM2VjRl7QIk, dostęp: 23.04.2017.

https://www.youtube.com/watch?v=0JWtcmMG5XQ, dostęp: 23.04.2017.

https://www.youtube.com/watch?v=uIoKP6dOlC4, dostęp: 24.05.2017.

https://www.youtube.com/watch?v=XVNggkLXP-Q\&list=PL24874077667666B2, dostęp:

15.09.2018.

http://kronikarp.pl/szukaj,34840,strona-2, dostęp: 20.05.2017.

http://kronikarp.pl/szukaj,34274,strona-3, dostęp: 23.04.2017.

http://kronikarp.pl/szukaj,32446,strona-2, dostęp: 23.04.2017.

http://kronikarp.pl/szukaj,33632,strona-3, dostęp: 23.04.2017.

http://kronikarp.pl/szukaj,34274,strona-3, dostęp: 23.04.2017.

http://kronikarp.pl/szukaj,1582,strona-2, dostęp: 23.04.2017.

http://kronikarp.pl/szukaj,32490,strona-2, dostęp: 23.04.2017.

http://www.kronikarp.pl/szukaj,34796,tag-692104,strona-1, dostęp: 23.04.2017.

http://kronikarp.pl/szukaj,34858,strona-2, dostęp: 23.04.2017.

http://kronikarp.pl/szukaj,32490,strona-2, dostęp: 23.04.2017.

http://kronikarp.pl/szukaj,31984,strona-3, dostęp: 23.04.2017.

http://kronikarp.pl/szukaj,42207,strona-3, dostęp: 23.04.2017.

http://kronikarp.pl/pop-up.php?id=34212\&type=2, dostęp: 22.05.2017.

http://kronikarp.pl/pop-up.php?id=11392\&type=2, dostęp: 22.05.2017.

http://kronikarp.pl/szukaj,12266,strona-2, dostęp: 9.07.2017.

http://kronikarp.pl/szukaj,33212,strona-2, dostęp: 9.07.2017.

http://kronikarp.pl/szukaj,53715,strona-3, dostęp: 9.07.2017.

http://kronikarp.pl/szukaj,55833,strona-2, dostęp: 9.07.2017.

http://kronikarp.pl/szukaj,11392,strona-2, dostęp: 24.05.2017.

http://kronikarp.pl/szukaj,42757,strona-2, dostęp: 9.07.2017.

http://kronikarp.pl/szukaj,55833,strona-2, dostęp: 9.07.2017.

http://kronikarp.pl/szukaj,53715,strona-3, dostęp: 9.07.2017.

http://kronikarp.pl/szukaj,13542,strona-2, dostęp: 22.05.2017.

http://kronikarp.pl/szukaj,32488,strona-2, dostęp: 20.05.2017.

http://www.repozytorium.fn.org.pl/?q=pl/node/9636, dostęp: 24.04.2017.

http://www.repozytorium.fn.org.pl/?q=pl/node/5792, dostęp: 23.04.2017.

Dziennik Ustaw RP z 1945 r. Nr 32, poz. 194.

Dziennik Ustaw RP z 1950 r. Nr 19, poz. 157.

Dziennik Ustaw RP z 1945 r. Nr 21, poz. 116.

Dziennik Ustaw RP z 1950 r. Nr 45, poz. 411. 


\section{Opracowania}

Borecki R., Propaganda a polityka, Warszawa 1987.

Cieśliński M., Piękniej niż w życiu: Polska Kronika Filmowa 1944-1994, Warszawa 2006.

Cieśliński M., Polska Kronika Filmowa: Podglądanie PRL-u, Warszawa 2016.

Dytman-Stasieńko A., 1 Maja w PRL: Święto zawłaszczonych znaczeń: ideologia, rytuał, język, Wrocław 2006.

Eisler J., Siedmiu wspaniałych. Poczet pierwszych sekretarzy KC PZPR, Warszawa 2014.

Gajdziński P., Gierek: człowiek z węgla, Poznań 2014.

Habuda L., Rzq̨dzq̨cy rzq̨dzeni: Totalitaryzm w stosunkach władzy w PRL, Opole 2001.

Jabłoński W., Kreowanie informacji. Media relations, Warszawa 2006.

Kotler P., Marketing. Analiza, planowanie, wdrażanie i kontrola, Warszawa 1994.

Kowalski L., Generał ze skazq, Poznań 2012.

Main I., Trudne świętowanie: Konflikty wokół obchodów świąt państwowych i kościelnych w Lublinie (1944-1989), Warszawa 2004.

Mazurek J., Z teorii propagandy socjalistycznej, Warszawa 1974.

Partia - państwo - społeczeństwo, red. R. Dudek i Z. Siembirowicz, Warszawa 1978.

Pietraś J.Z., Decydowanie polityczne, Warszawa 1998.

Pokorna-Ignatowicz K., Telewizja w systemie politycznym i medialnym PRL. Między polityka a widzem, Kraków 2003.

Rolicki J., Edward Gierek: Przerwana dekada: Wywiad rzeka, Warszawa 1990.

Rolicki J., Edward Gierek: Replika: Wywiad rzeka, Warszawa 1990.

Wielgosz J., Kierownicza rola PZPR wobec państwa i społeczeństwa socjalistycznego, Kraków 1971.

Zaremba M., Komunizm jako system mobilizacyjny - casus polski, [w:] Komunizm: ideologia, system, ludzie, Warszawa 2001.

Piotr Matura

\section{CREATION OF THE POLITICAL IMAGE OF EDWARD GIEREK IN THE POLISH FILM CHRONICLE - A NATIONAL ASPECT}

\footnotetext{
$\mathrm{T}$ he creation of a political image is one of the main elements of the election campaign in democratic countries, and in the authoritarian regimes of propaganda. For an effective politician, it can be extremely helpful in building his position in the country, or in the world.

The figure of Edward Gierek, after he took office of the First Secretary of the Central Committee of the Polish United Workers' Party, was very often present in various media. He also could not be miss in the Polska Kronika Filmowa. The new "First" definitely appreciated the importance of his positive presentation in the mass media, what was evident in the quantity and specificity of the materials associated with it. This paper deals with the analysis of how the First Secretary of the Central Committee of the PUWP was presented
} 
in this medium, presents certain patterns of the creation of his image, and outlines the changes taking place in it over the years.

The work includes specification of several planes and characteristic elements of the construction of Edward Gierek's image in the national context. This article is also trying to capture the goals of this creation. The author used the available literature on the subject, dealing with the Polska Kronika Filmowa as well as the political image. He also analyzed the available film materials and, above all, assembly lists, which were a detailed description of the chronicle editing, including a list of intakes with a description, as well as a lector's commentary.

Keywords: Polish Film Chronicle, propaganda, Edward Gierek, Polish People's Republic, Polish United Workers' Party, First Secretary of the Polish United Workers' Party (PZPR).

\section{ILUSTRACJE ${ }^{190}$}

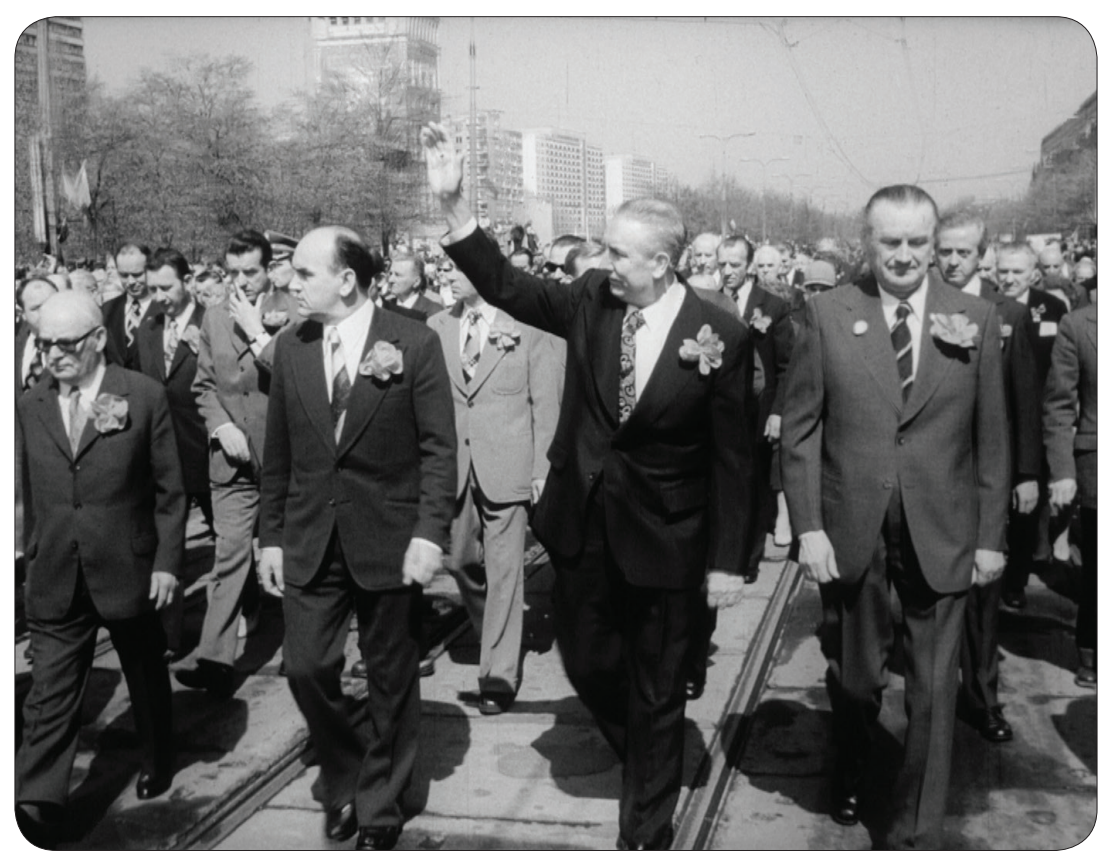

Fot. 1. Edward Gierek i „wierchuszka partyjna” podczas pochodu pierwszomajowego w 1975 r. PKF 18B/75

${ }^{190}$ Fot. 1-5. Copyright by Wytwórnia Filmów Dokumentalnych i Fabularnych. 


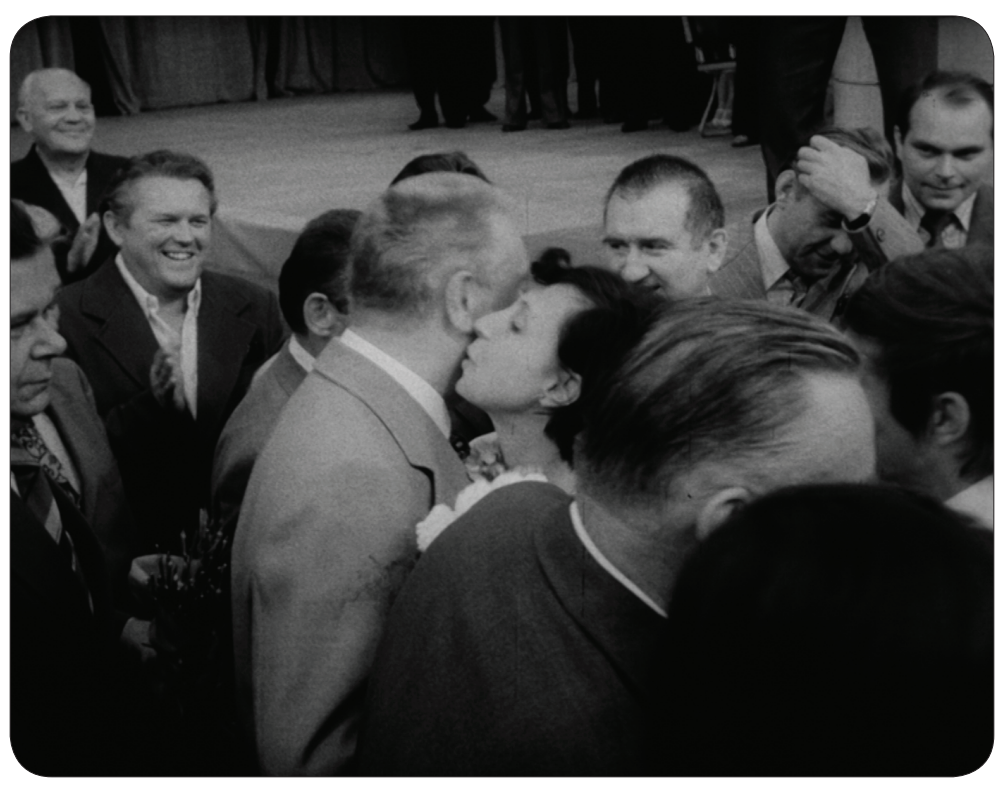

Fot. 2. Edward Gierek wśród uczestników wiecu poparcia w Katowicach, będącego odpowiedzią na wydarzenia w Ursusie i Radomiu w czerwcu 1976 r. PKF 28B/76

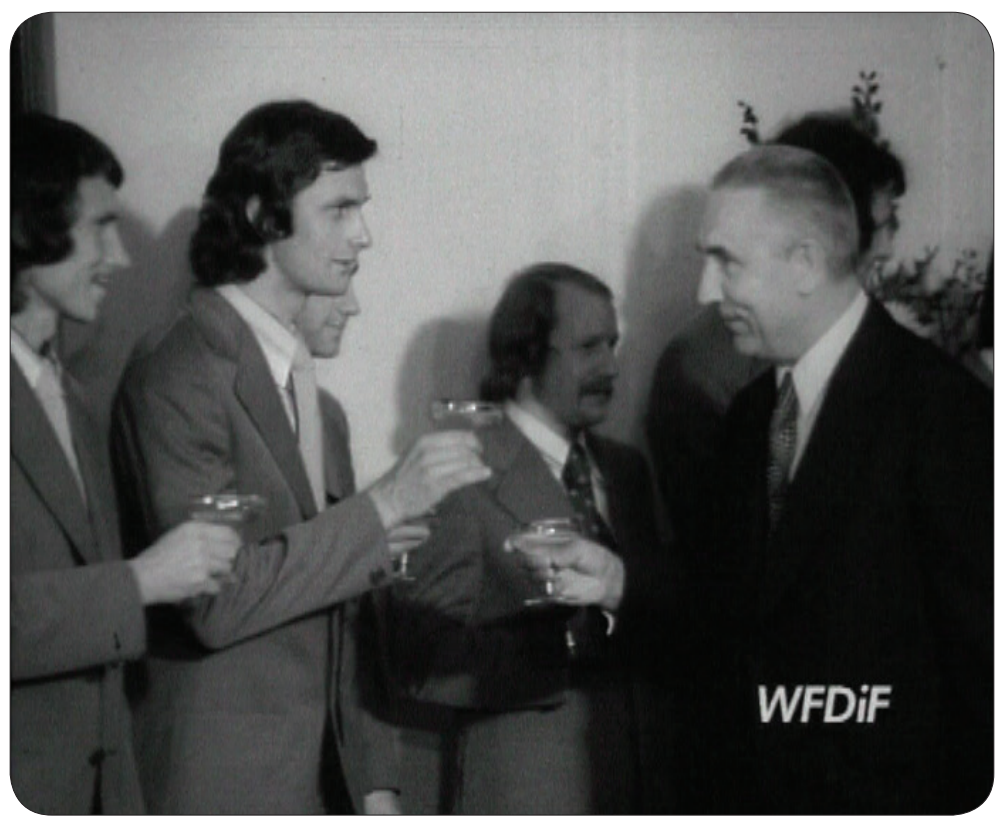

Fot. 3. Edward Gierek wita piłkarzy wracających do kraju z Mistrzostw Świata w Piłce Nożnej w 1974 r., podczas których reprezentacja Polski zajęła III miejsce. PKF 28B/74 


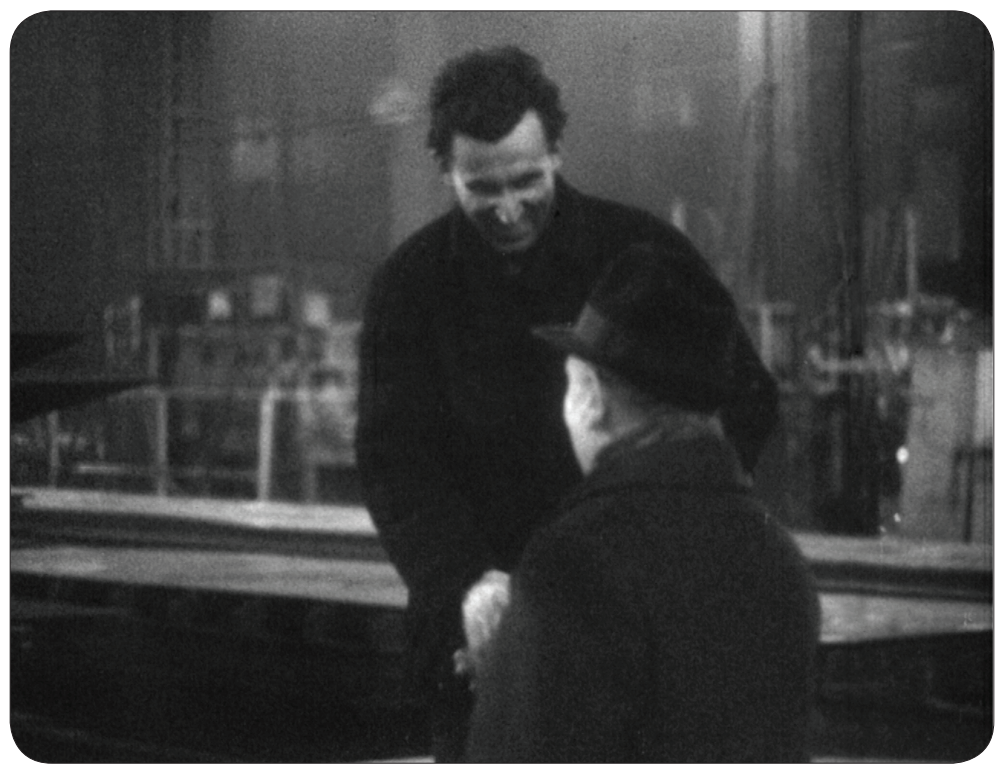

Fot. 4. Edward Gierek wita się z robotnikiem w Stoczni Szczecińskiej - początek 1971 r. PKF 4B/71

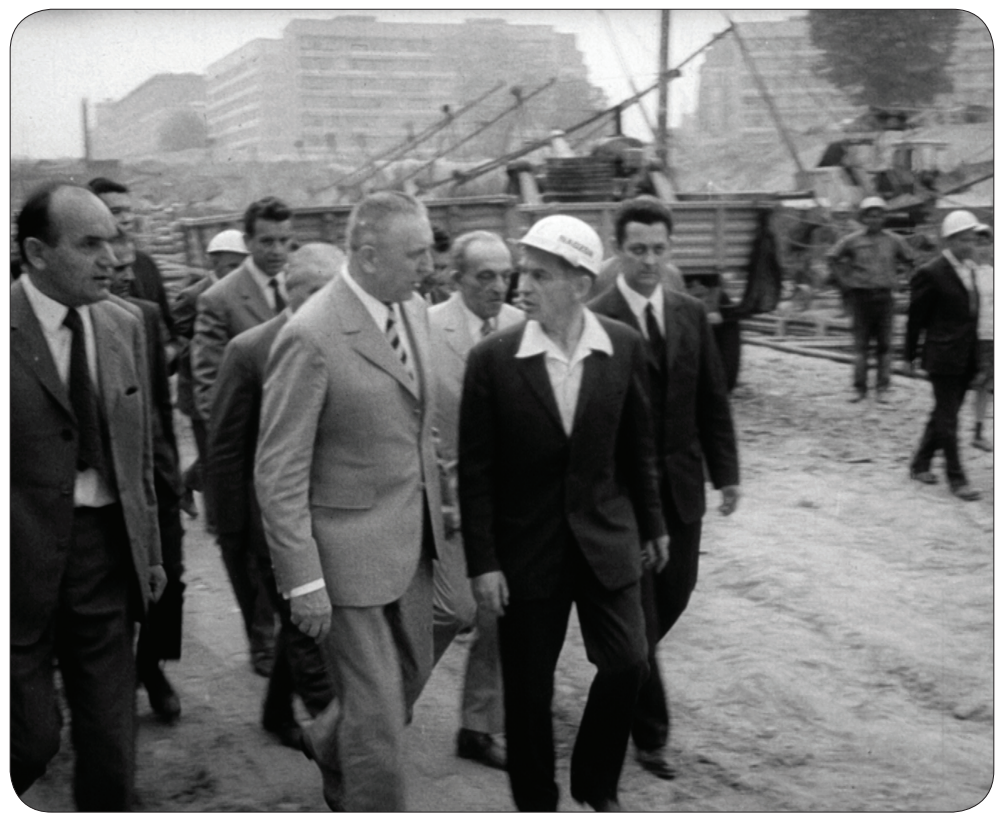

Fot. 5. Edward Gierek wizytujący plac budowy. Takie ujęcia w latach 1971-1977 były charakterystycznym elementem kroniki związanym z osobą I sekretarza. PKF 2A/73 